\title{
A consistent reaction scheme for the selective catalytic reduction of nitrogen oxides with ammonia
}

Janssens, Ton V.W.; Falsig, Hanne; Lundegaard, Lars Fahl; Vennestrøm, Peter N. R.; Rasmussen, Søren B.; Moses, Poul Georg; Giordanino, Filippo; Borfecchia, Elisa; Lomachenko, Kirill A.; Lamberti, Carlo Total number of authors:

14

Published in:

A C S Catalysis

Link to article, DOI:

$10.1021 / \mathrm{cs} 501673 \mathrm{~g}$

Publication date:

2015

Document Version

Peer reviewed version

Link back to DTU Orbit

Citation (APA):

Janssens, T. V. W., Falsig, H., Lundegaard, L. F., Vennestrøm, P. N. R., Rasmussen, S. B., Moses, P. G., Giordanino, F., Borfecchia, E., Lomachenko, K. Á., Lamberti, C., Bordiga, S., Godiksen, A., Mossin, S., \& Beato, P. (2015). A consistent reaction scheme for the selective catalytic reduction of nitrogen oxides with ammonia. $A$ C S Catalysis, 5(5), 2832-2845. https://doi.org/10.1021/cs501673g

\section{General rights}

Copyright and moral rights for the publications made accessible in the public portal are retained by the authors and/or other copyright owners and it is a condition of accessing publications that users recognise and abide by the legal requirements associated with these rights.

- Users may download and print one copy of any publication from the public portal for the purpose of private study or research.

- You may not further distribute the material or use it for any profit-making activity or commercial gain

- You may freely distribute the URL identifying the publication in the public portal 


\section{Article}

Subscriber access provided by DTU Library

\section{A consistent reaction scheme for the selective catalytic reduction of nitrogen oxides with ammonia}

Ton V.W. Janssens, Hanne Falsig, Lars Fahl Lundegaard, Peter Nicolai Ravnborg Vennestrøm, Søren Rasmussen, Poul Georg Moses, Filippo Giordanino, Elisa Borfecchia, Kirill A. Lomachenko, Carlo Lamberti, Silvia Bordiga, Anita Godiksen, Susanne Mossin, and Pablo Beato

ACS Catal., Just Accepted Manuscript • Publication Date (Web): 19 Mar 2015

Downloaded from http://pubs.acs.org on March 19, 2015

\section{Just Accepted}

"Just Accepted" manuscripts have been peer-reviewed and accepted for publication. They are posted online prior to technical editing, formatting for publication and author proofing. The American Chemical Society provides "Just Accepted" as a free service to the research community to expedite the dissemination of scientific material as soon as possible after acceptance. "Just Accepted" manuscripts appear in full in PDF format accompanied by an HTML abstract. "Just Accepted" manuscripts have been fully peer reviewed, but should not be considered the official version of record. They are accessible to all readers and citable by the Digital Object Identifier (DOIß). "Just Accepted" is an optional service offered to authors. Therefore, the "Just Accepted" Web site may not include all articles that will be published in the journal. After a manuscript is technically edited and formatted, it will be removed from the "Just Accepted" Web site and published as an ASAP article. Note that technical editing may introduce minor changes to the manuscript text and/or graphics which could affect content, and all legal disclaimers and ethical guidelines that apply to the journal pertain. ACS cannot be held responsible for errors or consequences arising from the use of information contained in these "Just Accepted" manuscripts. 


\title{
A consistent reaction scheme for the selective
} catalytic reduction of nitrogen oxides with ammonia

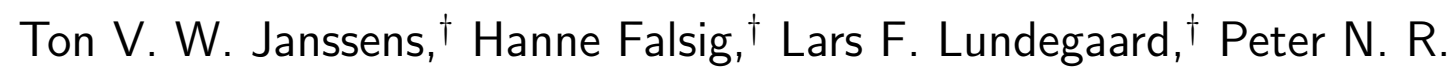 \\ Vennestrøm, ${ }^{\dagger}$ Søren B. Rasmussen, ${ }^{\dagger}$ Poul Georg Moses, ${ }^{\dagger}$ Filippo Giordanino, ${ }^{\ddagger}$ \\ Elisa Borfecchia,${ }^{\ddagger}$ Kirill A. Lomachenko,,+ Carlo Lamberti,,, Silvia Bordiga, ${ }^{*,+}$ \\ Anita Godiksen, ${ }^{\S}$ Susanne Mossin, ${ }^{*}, \S$ and Pablo Beato*,† \\ Haldor Topsøe A/S, Nymøllevej 55, 2800 Kgs. Lyngby, Denmark, Department of \\ Chemistry, NIS Centre of Excellence and INSTM Reference Center, University of Turin, \\ Via Giuria 7, 10125 Torino, Italy, Southern Federal University, Zorge Street 5, 344090 \\ Rostov-on-Don, Russia, and Department of Chemistry, Centre for Catalysis and \\ Sustainable Chemistry, Technical University of Denmark, Kemitorvet 207, 2800 Kgs. \\ Lyngby, Denmark \\ E-mail: siliva.bordiga@unito.it; sImo@kemi.dtu.dk; pabb@topsoe.dk
}

\footnotetext{
${ }^{*}$ To whom correspondence should be addressed

${ }^{\dagger}$ Haldor Topsøe

${ }^{\ddagger}$ University of Turin

`Southern Federal University Rostov-on-Don

$\S$ Technical University of Denmark
} 


\begin{abstract}
For the first time, the standard and fast selective catalytic reduction of NO by $\mathrm{NH}_{3}$ are described in a complete catalytic cycle, that is able to produce the correct stoichiometry, while only allowing adsorption and desorption of stable molecules. The standard SCR reaction is a coupling of the activation of $\mathrm{NO}$ by $\mathrm{O}_{2}$ with the fast SCR reaction, enabled by the release of $\mathrm{NO}_{2}$. According to the scheme, the SCR reaction can be divided in an oxidation of the catalyst by $\mathrm{NO}+\mathrm{O}_{2}$ and a reduction by $\mathrm{NO}$ $+\mathrm{NH}_{3}$; these steps together constitute a complete catalytic cycle. Furthermore both $\mathrm{NO}$ and $\mathrm{NH}_{3}$ are required in the reduction, and, finally, oxidation by $\mathrm{NO}+\mathrm{O}_{2}$ or $\mathrm{NO}_{2}$ leads to the same state of the catalyst. These points are shown experimentally for a $\mathrm{Cu}-\mathrm{CHA}$ catalyst, by combining in situ X-ray absorption spectrosocpy (XAS), electron paramagnetic resonance (EPR), and Fourier transform infrared spectroscopy (FTIR). A consequence of the reaction scheme is that all intermediates in fast SCR are also part of the standard SCR cycle. The calculated activation energy by density functional theory (DFT) indicates that the oxidation of an $\mathrm{NO}$ molecule by $\mathrm{O}_{2}$ to a bidentate nitrate ligand is rate determining for standard SCR. Finally, the role of a nitrate/nitrite equilibrium and the possible influence of $\mathrm{Cu}$ dimers and Brønsted sites are discussed, and an explanation is offered as to how a catalyst can be effective for SCR, while being a poor catalyst for $\mathrm{NO}$ oxidation to $\mathrm{NO}_{2}$.
\end{abstract}




\section{Keywords}

SCR, fast SCR, rate determining step, mechanism, Cu-CHA, NO oxidation, EPR, EXAFS, FTIR 


\section{Introduction}

The selective catalytic reduction of $\mathrm{NO}$ to $\mathrm{N}_{2}$ by ammonia $\left(\mathrm{NH}_{3}\right.$-SCR $)$ plays an important role in the abatement of $\mathrm{NO}_{\mathrm{x}}$ emissions in the exhausts of diesel engines and power plants. With the environmental legislation becoming more stringent in many places in the world, this reaction is going to play an important role in the development of technologies to meet the emission requirements for exhaust gases. The commercially available catalysts for exhaust gas cleaning by $\mathrm{NH}_{3}-\mathrm{SCR}$ are based on vanadium oxide supported on titanium oxide, Feexchanged zeolites, or Cu-exchanged zeolites. The traditional zeolites applied in SCR are ZSM-5, and zeolite $\beta$. More recently, Cu exchanged chabazites (CHA), in particular SSZ-13 and SAPO-34, have become more important, as these materials are more stable under high temperature conditions. Other known $\mathrm{Cu}$ - or Fe- exchanged zeolites with SCR activity are SSZ-39, ${ }^{1}$ ferrierite, mordenite. ${ }^{2,3}$

The composition and temperature of the exhaust gas from which the NO is to be removed depends on the source. In an automotive diesel engine, a typical exhaust gas contains up to a few hundred ppm of $\mathrm{NO}_{\mathrm{x}}, 5-10 \%$ water vapor, 5-10\% $\mathrm{O}_{2}$, hydrocarbons, $\mathrm{CO}$ and $\mathrm{CO}_{2}$. Ammonia is usually introduced by decomposition of urea to a concentration level of typically 1.0-1.2 times the NO concentration; the slight excess of ammonia ensures an efficient removal of the NO. In a typical exhaust aftertreatment system, the hydrocarbons and CO are removed upstream from the SCR catalyst, and hence the SCR catalyst is exposed to a mixture of $\mathrm{NO}_{\mathrm{x}}, \mathrm{O}_{2}, \mathrm{H}_{2} \mathrm{O}$, and $\mathrm{NH}_{3}$ in an inert gas $\left(\mathrm{N}_{2}\right.$ and $\left.\mathrm{CO}_{2}\right)$. The temperature at the SCR catalyst varies, and it is generally required that the SCR catalyst performs well in the temperature range $200-500{ }^{\circ} \mathrm{C}$. This gas composition and temperature range define the general operation conditions for an SCR catalyst system.

The key reaction in the $\mathrm{NH}_{3}$-SCR is the formation of nitrogen from $\mathrm{NO}$ and $\mathrm{NH}_{3}$ according to the equation:

$$
4 \mathrm{NH}_{3}+4 \mathrm{NO}+\mathrm{O}_{2} \rightarrow 4 \mathrm{~N}_{2}+6 \mathrm{H}_{2} \mathrm{O}
$$


This reaction is often referred to as 'standard SCR'. In the presence of $\mathrm{NO}_{2}$, nitrogen can also be formed according to

$$
2 \mathrm{NH}_{3}+\mathrm{NO}+\mathrm{NO}_{2} \rightarrow 2 \mathrm{~N}_{2}+3 \mathrm{H}_{2} \mathrm{O}
$$

Because this reaction is faster than the standard SCR reaction, ${ }^{4}$ it is often referred to as 'fast SCR'. In addition to these two reactions, a number of side reactions can occur in the mixture of $\mathrm{NO}_{\mathrm{x}}, \mathrm{O}_{2}, \mathrm{H}_{2} \mathrm{O}$, and $\mathrm{NH}_{3}$, such as formation of $\mathrm{N}_{2} \mathrm{O}$, or ammonia oxidation to $\mathrm{NO}_{\mathrm{x}}$. These side reactions do not directly contribute to the transformation of $\mathrm{NO}$ and $\mathrm{NH}_{3}$ to $\mathrm{N}_{2}$, but have an impact on the performance of the SCR catalyst, as they influence the selectivity for $\mathrm{N}_{2}$.

Due to the number of possible reactions in this system, the chemistry involved in the $\mathrm{NH}_{3}$ $\mathrm{SCR}$ reaction is rather complex. Consequently, the reaction mechanism for the $\mathrm{NH}_{3}-\mathrm{SCR}$ is still under discussion. In this article, first the key aspects of the SCR reaction mechanism are reviewed, and some shortcomings with the proposed reaction schemes are identified. Then we present a new reaction scheme that resolves these shortcomings in the present schemes, and corroborate the reaction scheme by means of density functional theory (DFT) calculations, X-ray absorption spectroscopy (XAS), electron paramagnetic resonance (EPR), and fourier transform infrared spectroscopy (FTIR) by example of a $\mathrm{Cu}-\mathrm{CHA}$ catalyst. Finally, the consequences of the proposed mechanism are discussed, leading to new insights in the role of the different reactants and intermediates, and in the chemistry behind the SCR reaction.

\section{Mechanistic aspects of the SCR reaction}

As mentioned in the introduction, the best known catalysts for SCR are supported vanadium oxide on titanium oxide, and $\mathrm{Cu}$ - and $\mathrm{Fe}$ - exchanged zeolites. The catalysts based on vanadium oxide and ion-exchanged zeolites all have an activity for redox reactions and acidic properties. For a V-based catalyst, a mechanism was proposed combining an acid cycle with 
a redox cycle. In the acid cycle, the ammonia is adsorbed and reacts with $\mathrm{NO}$ to $\mathrm{N}_{2}$ and $\mathrm{H}_{2} \mathrm{O}$, while reducing $\mathrm{V}^{5+}$ to $\mathrm{V}^{4+}$; the redox cycle restitutes the $\mathrm{V}^{5+}$ state of the catalyst through oxidation by oxygen and water. ${ }^{5}$ This scheme involves transfer of an H-atom from adsorbed $\mathrm{NH}_{3}$ to a neighboring $\mathrm{V}^{5+}=\mathrm{O}$ site. According to such a reaction scheme, at least two neighboring $\mathrm{V}$ atoms are involved in the SCR reaction. ${ }^{5,6}$ The SCR reaction can also take place on a single $\mathrm{V}$ atom, ${ }^{7}$ but the SCR reaction becomes significantly faster with the presence of polymeric $\mathrm{V}$ species. $^{8}$

In the $\mathrm{Cu}$ - and $\mathrm{Fe}$-exchanged zeolites, the oxidation properties are related to the ability of the exchanged ions to change oxidation state. ${ }^{9,10}$ In general, such catalysts also have Brønsted acidity, either since the standard procedures for $\mathrm{Cu}$ or Fe exchange do not result in a complete exchange or new protonic sites are formed as a result of a reduction of the metal ions. ${ }^{11}$ It is argued that the exchanged $\mathrm{Cu}$ or Fe ions facilitate the SCR reaction ${ }^{9,12-14}$ by oxidizing the $\mathrm{NO}$ to $\mathrm{NO}_{2}$, while the $\mathrm{SCR}$ reaction takes place elsewhere in the zeolite, ${ }^{15,16}$ which could be on the ammonia adsorbed on the Brønsted sites. If the Brønsted sites are located close to the $\mathrm{Cu}$ (or $\mathrm{Fe}$ ) ions in the zeolite, it is conceivable that an $\mathrm{NO}_{2}$ molecule on a $\mathrm{Cu}$ ion can interact directly with an $\mathrm{NH}_{3}$ molecule on a neighboring Brønsted site, which would make a reaction possible without the need for desorption of $\mathrm{NO}_{2} \cdot{ }^{17} \mathrm{Such}$ an interaction between an oxidation site and an acid site resembles that for the vanadium-oxide catalyst as mentioned above.

A consequence of the redox/acid cycle scheme is that the SCR activity of an ionexchanged zeolite becomes quite sensitive to the amount and distribution of the $\mathrm{Al}$ atoms in the framework of the zeolites. ${ }^{18-21}$ However, the role of the Brønsted sites in an ionexchanged zeolite is not well understood at present. For $\mathrm{Cu}-\mathrm{MFI}$ and $\mathrm{Cu}-\mathrm{CHA}$ zeolites it was found that the SCR activity at $200{ }^{\circ} \mathrm{C}$ is not dependent on the amount of Brønsted sites in these materials. This indicates that either the Brønsted sites do not play a role in the SCR reaction, or that these sites are always saturated with $\mathrm{NH}_{4}{ }^{+}$-ions under reaction conditions. ${ }^{12,22}$ Likewise, Brønsted sites in Fe-MFI catalysts are generally not required for 
high activity, but they could influence the distribution of the Fe ions or act as a promoter for the active Fe ions. ${ }^{23,24}$ All these results indicate that the SCR reaction takes place on the metal ions in $\mathrm{Cu}$ - or Fe-zeolites, with a limited influence of the Brønsted sites at most.

The distribution of the Al-framework atoms in a zeolite also affects the ability to form $\mathrm{Cu}$ - or Fe-dimers. After ion-exchange, the $\mathrm{Cu}$-atoms are coordinated to the oxygen atoms in $\mathrm{Si}-\mathrm{O}-\mathrm{Al}$-bridges, probably as a $\mathrm{Cu}^{2+}-\mathrm{OH}^{-}$unit, ${ }^{13,25-29}$ which has a total charge of +1 to balance the negative charge on the $\mathrm{Si}-\mathrm{O}-\mathrm{Al}$ site. Two neighboring $\mathrm{Cu}^{2+}-\mathrm{OH}^{-}$or $\mathrm{Cu}^{+}$units can combine to form a $\mathrm{Cu}-\mathrm{O}-\mathrm{Cu}$-structure, ${ }^{30-39}$ which is bound to two different $\mathrm{Al}$ atoms in the framework. It has been suggested that the formation of such $\mathrm{Cu}$-dimers enhances the SCR activity of $\mathrm{Cu}-\mathrm{SSZ}-13$, based on the observation that the activity per $\mathrm{Cu}$ atom increases with the Cu-loading. ${ }^{39,40}$

In $\mathrm{Cu}$-zeolites, the local environment of the $\mathrm{Cu}$ ions may be important for the SCR activity. Recently, it has been shown that the $\mathrm{Cu}$ ions in a $\mathrm{Cu}-\mathrm{CHA}$ zeolite are located in both the 6- and 8-rings of the chabazite framework structure. ${ }^{28,29,34,41}$ Upon adsorption of $\mathrm{NH}_{3}$, NO or $\mathrm{H}_{2} \mathrm{O}$ on the $\mathrm{Cu}$ atoms in the 6-rings, the $\mathrm{Cu}$ atoms are lifted out from their original position into the larger cavities in the zeolite, ${ }^{42-44}$ and therefore it seems that the $\mathrm{SCR}$ reaction actually takes place in the large cavities in $\mathrm{Cu}-\mathrm{CHA}$. However, only the $\mathrm{Cu}$ ions located in or close to the 6-rings seem to contribute to the SCR activity in Cu-CHA. ${ }^{12,45-48}$ Independent of the nature and structure of the catalyst, and the local environment of the active sites, the SCR reaction can be divided in a reduction part and an oxidation part, quite similar to the well known Mars-Van Krevelen scheme for oxidation reactions. The reduction part corresponds to the steps in which the ammonia reacts with the NO to nitrogen and the catalytic site is reduced. In the mechanism for SCR over supported vanadium oxide mentioned above, the acid cycle would represent the reduction part of the reaction. For $\mathrm{Cu}$-zeolites, it is proposed that the reduction takes place by adsorption of both NO and $\mathrm{NH}_{3}$ on $\mathrm{Cu}^{2+}$, leading to the formation of an ammonium nitrite or nitrate-like species, which decomposes to $\mathrm{N}_{2}$ and $\mathrm{H}_{2} \mathrm{O}$, while the $\mathrm{Cu}^{2+}$ is reduced to $\mathrm{Cu}^{+} .{ }^{40,49-51}$ The presence of $\mathrm{Cu}^{+}$ 
has been unambiguously identified by XAS under SCR conditions and infrared spectroscopy, even though the amounts may vary dependent on the zeolite type ${ }^{10,12,47,52,53}$ and the steady state conditions of the SCR reaction. This direct observation of $\mathrm{Cu}^{+}$confirms the idea that the SCR activity originates from the ability of the exchanged $\mathrm{Cu}$ to change the oxidation state. Besides $\mathrm{NH}_{3}$, NO also plays a role in reduction part of the SCR reaction. ${ }^{10,40,51}$ The formation of a $\mathrm{Cu}^{+}-\mathrm{NO}^{+}$species ${ }^{25,54}$ by adsorption of $\mathrm{NO}$ on $\mathrm{Cu}^{2+}$ at room temperature suggests that the $\mathrm{Cu}$ is actually reduced by $\mathrm{NO}$. On Fe-exchanged zeolites, the reduction follows essentially the same scheme as on $\mathrm{Cu}$-exchanged zeolites, with a reduction of $\mathrm{Fe}^{3+}$ to $\mathrm{Fe}^{2+}$ under the influence of $\mathrm{NH}_{3}$ and NO. ${ }^{10,15}$ However, Fe-zeolites show a more pronounced inhibition by $\mathrm{NH}_{3}$ for the $\mathrm{SCR}$ reaction, as compared to $\mathrm{Cu}$-zeolites. ${ }^{10,55}$

Whereas the reduction part of the SCR reaction seems quite well understood, the oxidation part is less clear. The oxidation part includes both the reoxidation of the catalytic site and the activation of NO. The reoxidation of the active site closes the catalytic cycle. This part of the reaction is often associated with the $\mathrm{O}_{2}$ that is needed for the SCR reaction, according to Eq. (1). ${ }^{5,9,10,40}$ The detailed steps describing this part of the reaction, however, are not known. An unsolved problem is that a single $\mathrm{Cu}$ - or Fe-ion only reduces the oxidation state by 1 , e.g. from $\mathrm{Cu}^{2+}$ to $\mathrm{Cu}^{+}$, and hence only delivers one electron, whereas an oxygen molecule requires four electrons to be reduced to water. As a consequence, if the oxidation reaction would take place with $\mathrm{O}_{2}$ only, a single oxygen molecule must interact with four $\mathrm{Cu}$ - or Fe-ions. Therefore, it is likely that the oxidation of the catalytic site is accompanied by another oxidation reaction at that site, such as the oxidaton of NO. This means that the activation of $\mathrm{NO}$ and the restoration of the catalytic site always occur together.

It is often argued that an activation of $\mathrm{NO}$ to (adsorbed) $\mathrm{NO}_{2}$ is necessary for the SCR reaction. ${ }^{15}$ Based on the fact that the SCR reaction becomes much faster in the presence of $\mathrm{NO}_{2}$, this step has also been proposed as the rate determining step for the standard SCR reaction. ${ }^{56-59}$ The adsorbed $\mathrm{NO}_{2}$ is the first step in the formation of reactive nitrate and nitrite species, ${ }^{15,40}$ which could occur by disproportionation of two $\mathrm{NO}_{2}$ molecules to 
$\mathrm{NO}_{3}{ }^{-}$and $\mathrm{NO}^{+}$, or alternatively by a reaction between $\mathrm{NO}$ and $\mathrm{NO}_{2}$ via an $\mathrm{N}_{2} \mathrm{O}_{3}$ intermediate. ${ }^{40}$ In the presence of $\mathrm{NH}_{3}$ and $\mathrm{H}_{2} \mathrm{O}, \mathrm{N}_{2} \mathrm{O}_{3}$ and $\mathrm{NO}^{+}$react further to ammonium nitrite $\mathrm{NH}_{4} \mathrm{NO}_{2}$, which readily decomposes to $\mathrm{N}_{2}$ and water. ${ }^{15,40}$ The $\mathrm{NO}_{3}{ }^{-}$species are transformed to ammonium nitrate, which upon decomposition may produce $\mathrm{N}_{2} \mathrm{O} .{ }^{40}$

Nitrates have also been considered as important intermediates for the fast SCR reaction over vanadium-oxide based catalysts. In particular it has been noticed that nitrates react with $\mathrm{NO}$ to give $\mathrm{NO}_{2} \cdot{ }^{60,61}$ This reaction is not confined to vanadium-oxide based systems, as exposure of nitrates in $\mathrm{Cu}$ or Fe-exchanged zeolites to $\mathrm{NO}$ also result in a transient release of $\mathrm{NO}_{2} \cdot{ }^{55,62-64}$ The opposite reaction also occurs: a direct exposure of an SCR catalyst to $\mathrm{NO}_{2}$ results in the formation of some NO. ${ }^{55,59,62,65}$ This indicates that nitrates can be converted to nitrites and vice versa, dependent on the gas atmosphere.

The conclusion that the oxidation of $\mathrm{NO}$ by $\mathrm{O}_{2}$ to $\mathrm{NO}_{2}$ is the rate determining step in the SCR reaction is challenged by Ruggeri et al. ${ }^{66}$ They compare the rate of NO oxidation over a $\mathrm{Cu}$-zeolite with the rate of the SCR reaction, and show that the NO oxidation is much slower in the entire temperature range $200-550{ }^{\circ} \mathrm{C}$, and that the effect of water is quite different for the NO oxidation compared to the SCR reaction. It is argued that if the $\mathrm{NO}_{2}$ formation were a part of the SCR reaction, then the rates of the NO oxidation and SCR reactions should be similar, as well as the effect of water on them. Following this argument, the formation of $\mathrm{NO}_{2}$ can not be part of the SCR reaction. A point against this reasoning is that $\mathrm{NO}_{2}$ can be formed, but does not desorb from the Cu-sites, under the given conditions. ${ }^{59,61,64,67}$ In that case, the SCR reaction would involve a reaction of adsorbed $\mathrm{NO}_{2}$ with ammonia adsorbed on $\mathrm{Cu}$, and not the Brønsted sites. Temperature-programmed desorption of $\mathrm{NO}_{2}$ on $\mathrm{Cu}-\mathrm{CHA}$, however, shows that the onset of $\mathrm{NO}_{2}$ desorption is around $300{ }^{\circ} \mathrm{C}$ and is complete around $450{ }^{\circ} \mathrm{C} .{ }^{59,61}$ This would imply that, at least above $450{ }^{\circ} \mathrm{C}$, the rate of $\mathrm{NO}_{2}$ formation should approach that of the SCR reaction, if the desorption of $\mathrm{NO}_{2}$ were rate limiting. Ruggeri et al. suggest that the rate determining steps for $\mathrm{SCR}$ and $\mathrm{NO}_{2}(\mathrm{~g})$ formation are different: for $\mathrm{NO}$ oxidation, it is the release of $\mathrm{NO}_{2}$ from a surface nitrite, for SCR it is the reaction of 
surface nitrites with $\mathrm{NH}_{3} \cdot{ }^{66}$ At this moment it is not known why Cu-exchanged zeolites are effective SCR catalysts, and at the same time poor catalysts for the oxidation of $\mathrm{NO}$ to $\mathrm{NO}_{2}$.

In conclusion, there have been several proposals for the mechanism for the SCR reaction. The consensus is that the $\mathrm{N}_{2}$ is formed by a reaction between ammonia and a $(\mathrm{N}, \mathrm{O})$ species, which is accompanied by a reduction of the catalytic site. It is also clear that the oxidation of NO plays a role in the reoxidation of the catalytic site. However, we note that most of the proposed reaction schemes are not able to produce the stoichiometry of the SCR reaction as given in Eq. (1) in a closed catalytic cycle. Often, single oxygen atoms, fractional molecules $\left(\frac{1}{2} \mathrm{O}_{2}\right)$ or isolated ions, such as $\mathrm{H}^{+}, \mathrm{OH}^{-}$and $\mathrm{O}^{2-}$, are invoked. Such species are not readily available and also imply other changes to the catalyst: the use of a single $\mathrm{H}^{+}$ion leaves an isolated negative charge on the catalyst, or the second oxygen atom in $\frac{1}{2} \mathrm{O}_{2}$ must be accommodated in the catalyst. These changes have to be restored as well in order to close the catalytic cycle. In the following we construct a reaction scheme for the SCR reaction on a $\mathrm{Cu}$-exchanged zeolite, which is consistent with the stoichiometry of the SCR reaction as given in Eq. (1), and involves only adsorption and desorption of stable molecules. The proposed reaction scheme is supported by spectroscopy and DFT calculations. Some implications of the reaction scheme are discussed, leading to new insights in the SCR reaction and a deeper understanding of the role of $\mathrm{NO}, \mathrm{NH}_{3}, \mathrm{NO}_{2}$ and the adsorbed nitrate (and nitrite) species, which are often observed in in situ and operando spectroscopic studies of the SCR reactions.

\section{A consistent reaction scheme for SCR}

The variety of proposed reaction schemes for the SCR reaction in the literature is a consequence of the fact that several different reactions can occur simultaneously in a gas mixture of $\mathrm{NO} / \mathrm{NH}_{3} / \mathrm{O}_{2} / \mathrm{H}_{2} \mathrm{O}$ in the presence of an oxidation catalyst with acidic properties. In most cases, the proposed reaction schemes are based on in situ spectroscopic observations of certain species, and it is then attempted to give these particular species a place in the reaction 
scheme. The problem with this approach is that it is hard to determine, if a given species that is observed actually plays a role in the SCR reaction, or is part of a side reaction, or just a spectator species. ${ }^{68}$ Obviously, this complicates the process of finding a consistent reaction scheme for the SCR reaction.

To overcome that problem, we have taken a different approach. Instead of starting with a number of possible reaction intermediates, we have focused on the SCR reaction as given in Eq. (1), and attempted to outline how this reaction could proceed on a Cu-exchanged zeolite, given that the reaction gas mixture contains $\mathrm{O}_{2}, \mathrm{NO}, \mathrm{NO}_{2}, \mathrm{NH}_{3}, \mathrm{~N}_{2}$, and $\mathrm{H}_{2} \mathrm{O}$. Furthermore, we imposed the following requirements:

1. In each reaction step, the mass balance is maintained, and the complete catalytic cycle is consistent with the total stoichiometry of the SCR reaction, Eq. (1)

2. adsorption from and desorption to the gas phase can only take place with stable molecules: $\mathrm{O}_{2}, \mathrm{NO}, \mathrm{NO}_{2}, \mathrm{NH}_{3}, \mathrm{~N}_{2}$, and $\mathrm{H}_{2} \mathrm{O}$, implying that adsorption or desorption of fragments, such as $\frac{1}{2} \mathrm{O}_{2}$, or isolated ions, e.g. $\mathrm{OH}^{-}, \mathrm{H}^{+}, \mathrm{O}^{2-}$ is not allowed

3. the oxidation state for the active $\mathrm{Cu}$ ion changes from +2 to +1 in the reduction part, and from +1 to +2 in the oxidation part

4. in each step, the charge balance is maintained and the total charge of the Cu-complexes in the zeolite is always +1 , allowing for coordination to a single $\mathrm{Si}-\mathrm{O}^{-}-\mathrm{Al}$ site in the zeolite.

In this way, we construct a reaction scheme for the SCR reaction only, which means that we do not consider side reactions, such as oxidation of $\mathrm{NH}_{3}$ by $\mathrm{O}_{2}$, or the formation of $\mathrm{N}_{2} \mathrm{O}$.

Scheme 1 shows a reaction scheme for a $\mathrm{Cu}$-zeolite that fulfills all requirements mentioned above. This reaction scheme can be regarded as the simplest possible reaction path for the SCR reaction.

The key point in this reaction scheme is the formation of an $\mathrm{NO}_{2}$ molecule in the gas phase by reaction of $\mathrm{NO}$ with an adsorbed nitrate species, leaving a nitrite species on the 


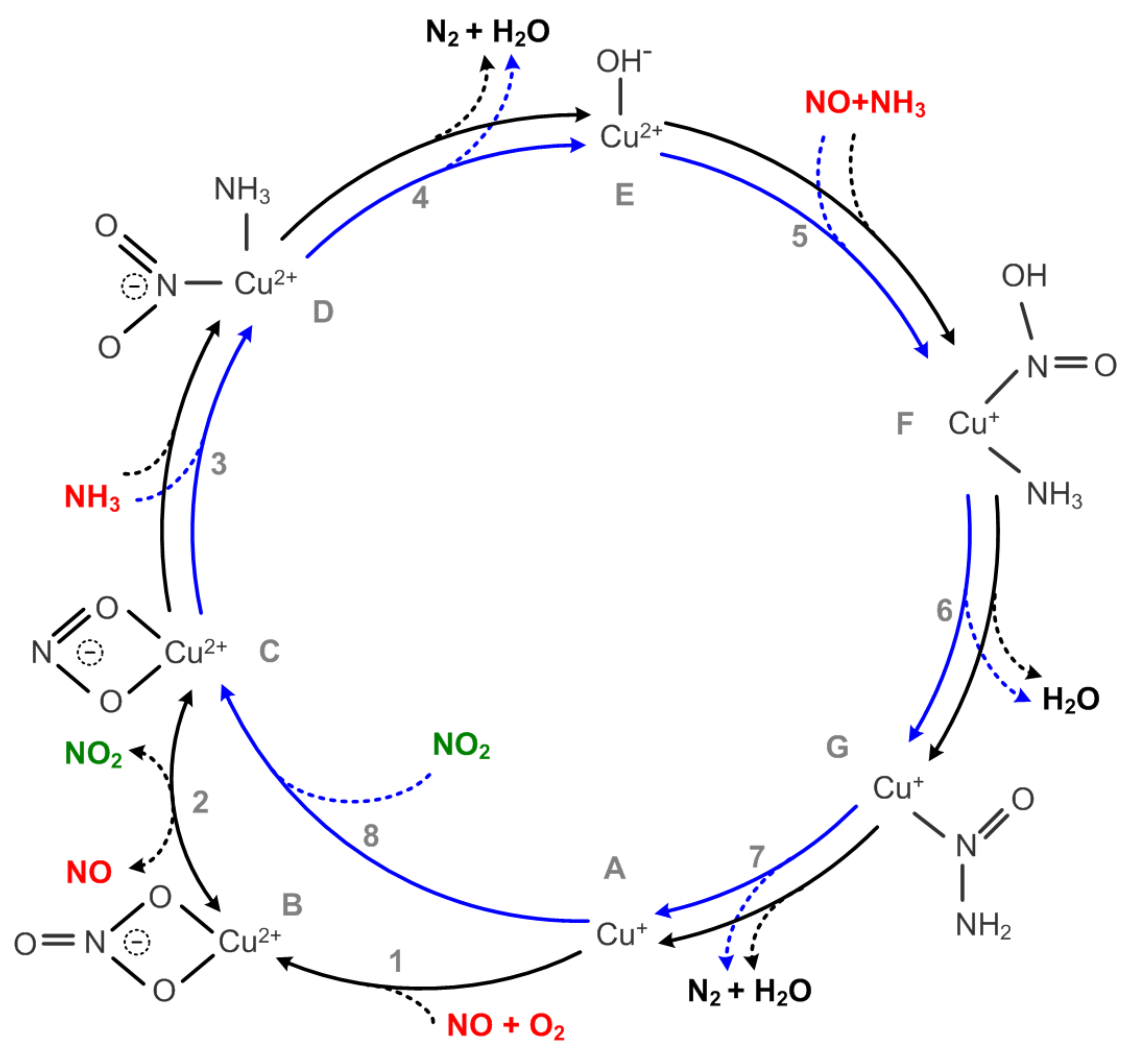

Scheme 1: Proposed reaction mechanism for the SCR reaction in a Cu-zeolite. The fast SCR cycle is represented in blue, and the $\mathrm{NO}$ activation cycle is represented in black. Reactants are indicated in red, reaction products are indicated in black, the $\mathrm{NO}_{2}$ intermediate is indicated in green. In the standard SCR reaction, Eq. (1) the NO activation cycle and fast SCR cycle run at equal rates; the stoichiometry of the standard SCR reaction is then found by adding these two cycles. The oxidation states of the $\mathrm{Cu}$ ions have been assigned according to the magnetic moment found in DFT: $M\left(\mathrm{Cu}^{2+}\right)>0.45$ and $M\left(\mathrm{Cu}^{+}\right)<0.1$

$\mathrm{Cu}$ atom (step 2). The $\mathrm{NO}_{2}$ molecule reacts with a $\mathrm{Cu}^{+}$ion elsewhere in the zeolite to an identical nitrite species (step 8). Both nitrites react with ammonia and NO and release water and nitrogen, via $\mathrm{Cu}^{2+}-\mathrm{OH}^{-}$species, to a $\mathrm{Cu}^{+}$; this corresponds to the reduction part of the SCR reaction. The $\mathrm{Cu}^{+}$site then reacts either with $\mathrm{NO}$ and $\mathrm{O}_{2}$ or with $\mathrm{NO}_{2}$ to form the nitrate and nitrite species, closing the catalytic cycle; this corresponds to the oxidation part of the SCR reaction. Scheme 1 shows that it is conceivable that the entire SCR reaction can take place on a single, isolated $\mathrm{Cu}$ site, without the need of Brønsted sites or $\mathrm{Cu}$ dimers. In fact, the reaction scheme does not require a specific location or configuration of the $\mathrm{Cu}$-ions. Similar reaction schemes, containing the formation of $\mathrm{NO}_{2}$ from a nitrate species to form two 
identical nitrite species, can be constructed for $\mathrm{Cu}$ in 6-rings or 8-rings, and also $\mathrm{Cu}$-dimers, or other metal ions capable of 1-electron redox reactions, e.g. Fe-zeolites or vanadium oxide, or other, oxide based catalysts.

The stoichiometry of the standard SCR reaction arises from the coupling of the two reaction cycles via the $\mathrm{NO}_{2}$ that is released. The inner cycle in Scheme 1, containing the reaction of $\mathrm{NO}_{2}$ with a $\mathrm{Cu}^{+}$, is in fact the fast SCR reaction, according to Eq. (2), and hence it is intrinsically faster than the outer cycle. In this article, we refer to the steps in the inner cycle as "fast-SCR cycle" (blue arrows in Scheme 1), and the steps in the outer cycle as "NO-activation cycle" (black arrows in Scheme 1). The NO-activation cycle can be written as:

$$
2 \mathrm{NH}_{3}+3 \mathrm{NO}+\mathrm{O}_{2} \rightarrow 2 \mathrm{~N}_{2}+3 \mathrm{H}_{2} \mathrm{O}+\mathrm{NO}_{2}
$$

Note that the NO-activation cycle includes the same reduction steps as the fast-SCR cycle.

In standard SCR, there is no excess $\mathrm{NO}_{2}$, and the rate of the fast-SCR cycle is limited by the amount of $\mathrm{NO}_{2}$ available. As a result, the overall rates of the fast-SCR and NOactivation cycles become equal. The reaction steps in the NO-activation cycle are always accompanied by the reaction steps in the fast-SCR cycle at an equal rate; the result is the standard SCR reaction. It is noted that the steps in the fast-SCR cycle can occur isolated, provided $\mathrm{NO}_{2}$ is available; this is the fast SCR reaction.

The total stoichiometry of the standard SCR reaction then follows from addition of the NO-activation and fast-SCR cycles in Scheme 1, and Eqs. (2) and (3). Ruggeri et al. have noted that the standard SCR reaction can be written as the sum of the oxidation of NO to $\mathrm{NO}_{2}$, according to $2 \mathrm{NO}+\mathrm{O}_{2} \longrightarrow 2 \mathrm{NO}_{2}$, and the fast SCR reaction (Eqs. 2). ${ }^{66}$ Scheme 1 is actually a representation of that, with nitrite figuring as one of the $\mathrm{NO}_{2}$ species.

The coupling of the NO-activation and fast-SCR cycles, as proposed here, has two important consequences for a fundamental understanding of the standard and fast SCR reactions. 
First, as the fast-SCR cycle is intrinsically faster than the outer cycle, the rate determining step in standard SCR must involve the oxidation of NO to nitrates or nitrites, or the release of $\mathrm{NO}_{2}$. The second consequence is that the chemistry of the standard SCR and fast SCR reactions essentially is the same: all reaction intermediates in the fast SCR reaction are also part of the standard SCR reaction.

It is stressed here that the reaction intermediates shown in Scheme 1 are constructed according to the requirements given above, and are presented as a hypothesis at this point. Any other reaction scheme containing the element of a slow formation of $\mathrm{NO}_{2}$ from $\mathrm{NO}$ and $\mathrm{O}_{2}$ in combination with a fast-SCR step also will result in the correct stoichiometry for the SCR reaction, and may be equally valid. Scheme 1 seems nevertheless reasonable, as it contains the known $\mathrm{NO}_{3}^{-}, \mathrm{NO}_{2}^{-}, \mathrm{OH}^{-}, \mathrm{HO}-\mathrm{NO}$ and $\mathrm{NH}_{3}$ ligands. The reaction path from $\mathrm{Cu}^{2+}-\mathrm{OH}^{-}$to $\mathrm{Cu}^{+}$consists of the same reaction steps as proposed earlier, ${ }^{10,51}$ and the presence of nitrates in an SCR catalyst is also well documented. ${ }^{50,62,63,69,70}$ Scheme 1 is in full agreement with the conclusions that $\mathrm{Cu}^{2+}$ is reduced by the combination of $\mathrm{NO}+\mathrm{NH}_{3}$, followed by an oxidation by $\mathrm{NO}+\mathrm{O}_{2} \cdot{ }^{49}$ A reaction between $\mathrm{NO}$ and nitrate to $\mathrm{NO}_{2}$ has been observed in SCR over both V-based and zeolite-based catalysts, ${ }^{60,61}$ and the reverse reaction releasing $\mathrm{NO}$ upon exposure to $\mathrm{NO}_{2}$ is also known. ${ }^{55,62,63,71}$ The difference between Scheme 1 and previously proposed reaction schemes does not lie in the individual reaction steps or reaction intermediates, but in the description of the standard SCR reaction as a coupling of an $\mathrm{NO}$ oxidation step with the fast $\mathrm{SCR}$ reaction via an $\mathrm{NO}_{2}$ molecule.

\subsection{Verification of the reaction scheme}

To verify the reaction steps shown in Scheme 1 for SCR reactions, the energy profile of the NO-activation cycle at $200{ }^{\circ} \mathrm{C}$ was calculated by DFT.

Furthermore, a $\mathrm{Cu}-\mathrm{CHA}$ catalyst with a $\mathrm{Si} / \mathrm{Al}$ ratio of 15 and a $\mathrm{Cu} / \mathrm{Al}$ ratio of 0.48 , corresponding to a total $\mathrm{Cu}$-loading of $2.6 \mathrm{wt} \% \mathrm{Cu}$, was characterized by XAS, EPR and FTIR. First, the reduction and oxidation steps were decoupled to obtain insight in the state 
of the $\mathrm{Cu}$ and the ligands present in these different phases of the SCR reaction. Then, the same techniques are also used to verify that the state of the $\mathrm{Cu}$ obtained by oxidation by $\mathrm{NO}$ and $\mathrm{O}_{2}$ or by $\mathrm{NO}_{2}$ is the same. Finally, the role of nitrates and nitrites and their formation by $\mathrm{NO}+\mathrm{O}_{2}$ and by $\mathrm{NO}_{2}$ is studied in more detail. In all these measurements, the temperature was kept at $200{ }^{\circ} \mathrm{C}$.
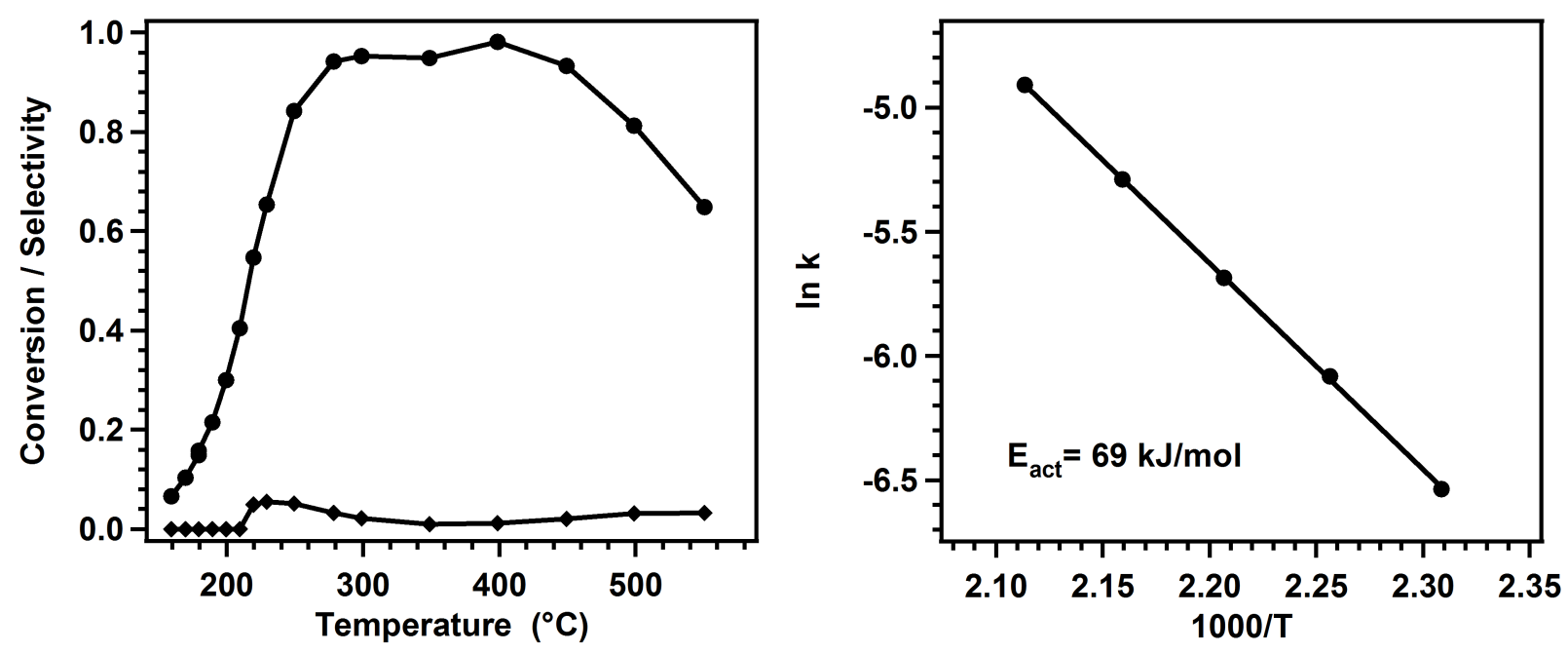

Figure 1: Left panel: Measured conversion of $\mathrm{NO}$ (circles) and selectivity to $\mathrm{N}_{2} \mathrm{O}$ (diamonds) in the temperature range $160-550{ }^{\circ} \mathrm{C}$. Amount of catalyst: $5 \mathrm{mg}$. Feed gas: $500 \mathrm{ppm} \mathrm{NO}$, 533 ppm $\mathrm{NH}_{3}, 5 \% \mathrm{H}_{2} \mathrm{O}, 10 \% \mathrm{O}_{2}$ in $\mathrm{N}_{2}$. Flow: $225 \mathrm{Nml} / \mathrm{min}$. Right panel: Arrhenius plot of the rate constant, assuming a first order rate equation $r=k p_{N O}$; the slope corresponds to an activation energy of $69 \mathrm{~kJ} / \mathrm{mol}$.

The Cu-CHA catalyst used in these characterizations is an efficient SCR catalyst. Figure 1 shows the $\mathrm{NO}$ conversion and $\mathrm{N}_{2} \mathrm{O}$ selectivity measured in a microreactor in the temperature range $160-550{ }^{\circ} \mathrm{C}$. The NO conversion shows a bimodal pattern, with a first maximum around $300{ }^{\circ} \mathrm{C}$ and a second maximum around $400{ }^{\circ} \mathrm{C}$, similar to earlier observations..$^{39,40}$ The decreasing NO-conversion above $400{ }^{\circ} \mathrm{C}$ can be ascribed to an enhanced direct oxidation of ammonia to NO that occurs in this temperature range. It is noted that this particular $\mathrm{Cu}-\mathrm{CHA}$ catalyst is very selective: $\mathrm{N}_{2} \mathrm{O}$ is the only byproduct, with a maximum selectivity of about $6 \%$ at $230{ }^{\circ} \mathrm{C}$.

The activation energy is derived from the NO conversion data in the temperature range 160-200 ${ }^{\circ} \mathrm{C}$. Assuming that the SCR reaction is first order in NO and zeroth order in 
$\mathrm{NH}_{3},{ }^{50,56,72}$ the rate constants for the SCR reaction in this temperatures are evaluated. From the slope of the Arrhenius plot of these data, shown in the right panel in Figure 1, an apparent activation energy of $69 \mathrm{~kJ} / \mathrm{mol}$ is found, which is within the range of activation energies reported earlier. ${ }^{39,72}$

\subsubsection{Stability of intermediates and energy diagram calculated by DFT}

In each reaction step shown in Scheme 1, a molecule is adsorbed or desorbed from the $\mathrm{Cu}$ site, or both. The ligands on the $\mathrm{Cu}$ site then follow from the mass balance at each step. In the following, the stability of the different reaction intermediates as calculated by DFT is discussed, to show that the proposed reaction steps in Scheme 1 are reasonable.

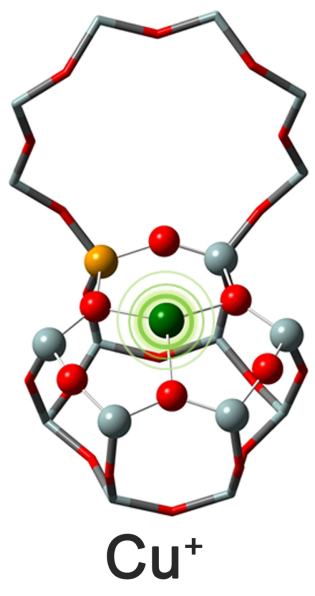

double 6-ring

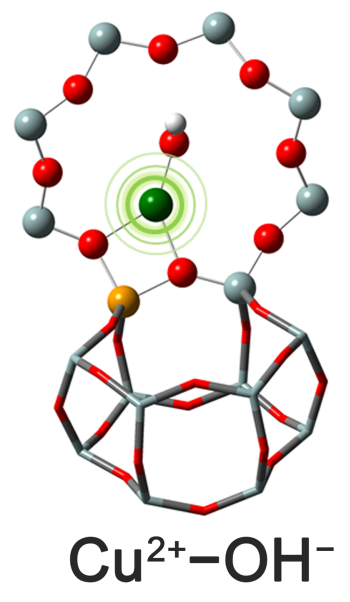

8-ring

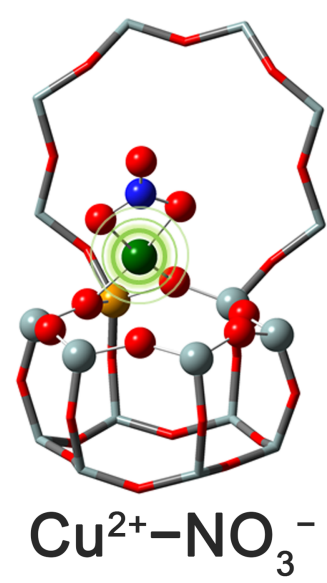

double 6-ring

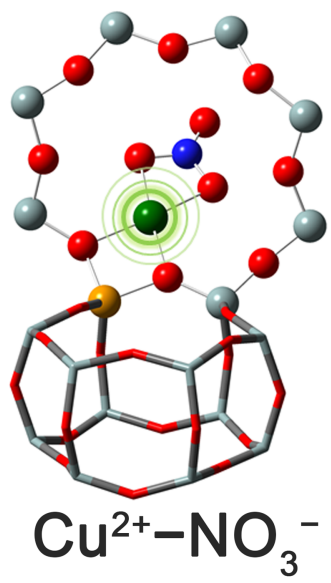

8-ring

Figure 2: Model geometries of $\mathrm{Cu}^{+}, \mathrm{Cu}^{2+}-\mathrm{OH}^{-}$, and $\mathrm{Cu}^{2+}-\mathrm{NO}_{3}{ }^{-}$in a 6-ring and an 8-ring configuration in CHA. Atoms are colored as follows: Si: grey, Al: yellow, Cu: green, N: blue, O: red, H: white

From DFT, we find that the most stable geometry of $\mathrm{Cu}^{+}$is in the double 6-ring and that of $\mathrm{Cu}^{2+}-\mathrm{OH}^{-}$in the 8-ring, as shown in Figure 2. These two locations for the $\mathrm{Cu}$ ions are well known from structural analysis of $\mathrm{Cu}-\mathrm{CHA}$ catalysts, although some controversy exists on which form actually constitutes the active site. $6,12,28,34,39-41,44,52,72,73$ However, when adsorbates are present, the $\mathrm{Cu}$ ion is lifted out of the 6-ring plane and the preference for the 6-ring location diminishes. ${ }^{42,43,74}$ This is also observed for the formation of $\mathrm{Cu}^{2+}-\mathrm{NO}_{3}{ }^{-}$ 
(step 1), where the difference in energy for the $\mathrm{Cu}$ located in the 8-ring is only 0.08 eV lower compared to the $\mathrm{Cu}$ in the 6-ring, showing that there is no real preference for location of the $\mathrm{Cu}$ in the 6-ring or 8-ring in this case.

The ligands in the different steps in Scheme 1 represent the most stable configuration found with DFT for the given stoichiometry. However, the order of two consecutive adsorption steps, e.g. the adsorption of $\mathrm{NO}$ and $\mathrm{NH}_{3}$ (step 5), or $\mathrm{NO}$ and $\mathrm{O}_{2}$ (step 1), is arbitrary, as it at the end produces the same intermediate. According to Scheme 1 , the $\mathrm{Cu}^{2+}-\mathrm{OH}^{-}$ (species E) reacts with both $\mathrm{NH}_{3}$ and $\mathrm{NO}$ to $\mathrm{N}_{2}$ and $\mathrm{H}_{2} \mathrm{O}$, while the $\mathrm{Cu}^{2+}$ is reduced to $\mathrm{Cu}^{+}$; this part is the heart of the SCR reaction. After adsorption of the $\mathrm{NO}$ and $\mathrm{NH}_{3}$, the stoichiometry of the ligands corresponds to that of ammonium nitrite, and from here, a decomposition to water and nitrogen takes place. The calculated adsorption energy of NO on the $\mathrm{Cu}^{2+}-\mathrm{OH}^{-}$(species $\mathrm{E}$ ) is $-1.05 \mathrm{eV}$ to yield a $\mathrm{NO}^{+}-\mathrm{Cu}^{+}-\mathrm{OH}^{-}$species and $-1.14 \mathrm{eV}$ to yield a $\mathrm{Cu}^{+}-\mathrm{HONO}-$ like species; these species are quite similar to the $\mathrm{Cu}^{+}-\mathrm{NO}^{+}$species proposed earlier. ${ }^{40,75}$ The corresponding adsorption of $\mathrm{NH}_{3}$, resulting in a $\mathrm{Cu}^{2+}-\mathrm{NH}_{3}-\mathrm{OH}^{-}$ species, is $-0.93 \mathrm{eV}$. As these values are quite close, the actual order of adsorption of NO and $\mathrm{NH}_{3}$ seems more or less random.

An important result for the SCR reaction mechanism is that adsorption of $\mathrm{O}_{2}$ takes place on the $\mathrm{Cu}^{+}$species. The calculated adsorption energy at $0 \mathrm{~K}$ of $\mathrm{O}_{2}$ on $\mathrm{Cu}^{+}$(species $\mathrm{A}$ in Scheme 1) is $-0.66 \mathrm{eV}$. On the $\mathrm{Cu}^{2+}-\mathrm{OH}^{-}$ion (species E), the calculated adsorption energy is positive and no adsorption takes place. This indicates that $\mathrm{O}_{2}$ only takes part in the reoxidation of the $\mathrm{Cu}^{+}$.

Figure 3 shows the energy diagram of the reaction steps of the NO-activation cycle shown in Scheme 1 (black arrows). The SCR reaction is strongly exothermic, and all the steps in the reduction part of the reaction, involving the reaction with $\mathrm{NH}_{3}$ and $\mathrm{NO}$, are exothermic, which is consistent with a fast and effective reduction of the $\mathrm{Cu}^{2+}-\mathrm{OH}^{-}$(species E) to the $\mathrm{Cu}^{+}$(species $\mathrm{A}$ ) in a mixture of $\mathrm{NO}$ and $\mathrm{NH}_{3}$. In the oxidation part of the reaction, the adsorption of $\mathrm{NO}+\mathrm{O}_{2}$ and formation of the nitrate are exothermic, but the formation of 


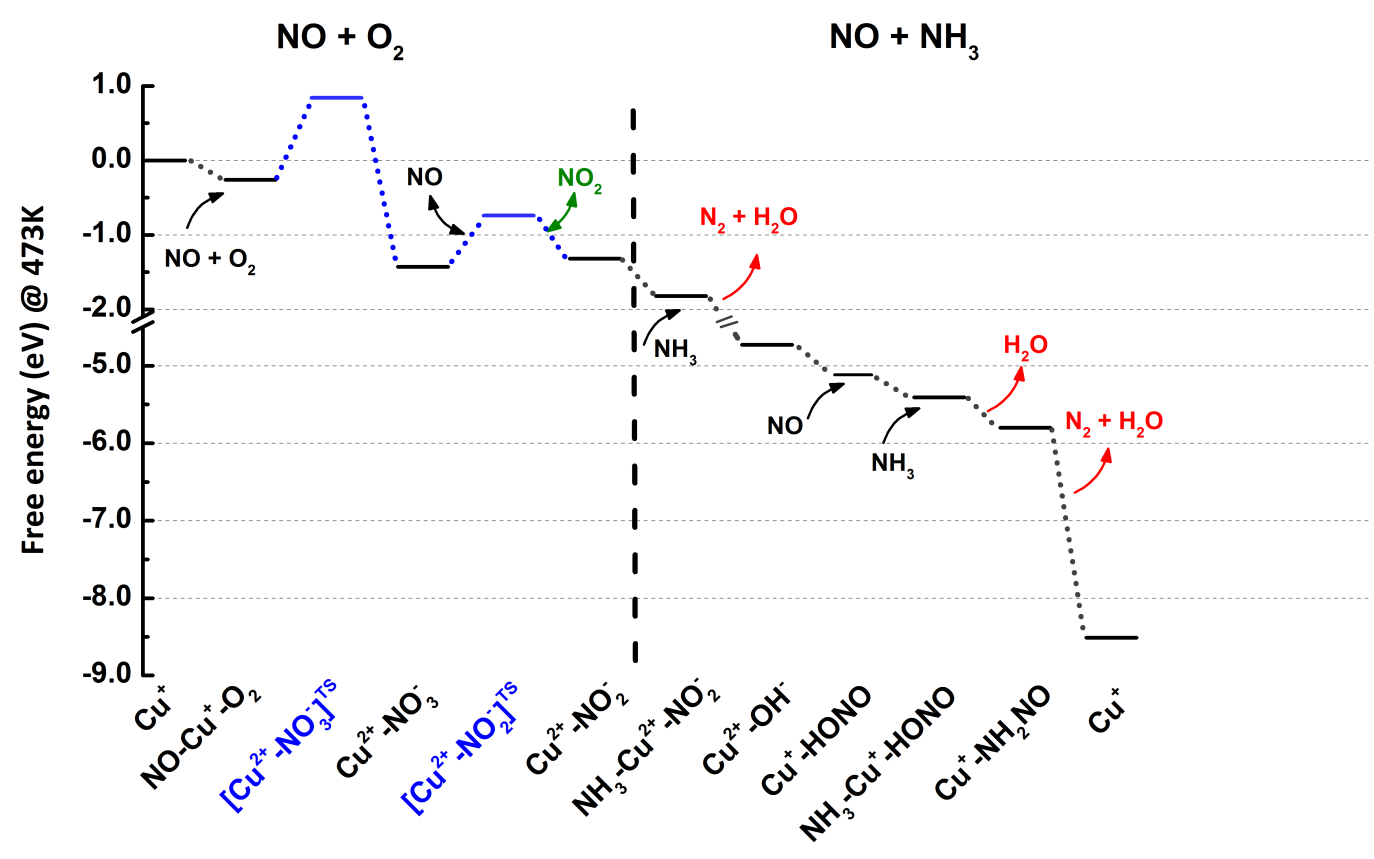

Figure 3: Calculated free energy diagram for the NO activation cycle shown in Scheme 1. The free energies at each level are given relative to $\mathrm{Z}-\mathrm{Cu}^{+}$, and the appropriate gas phase molecules. Calculated activation energies in the oxidation part are shown in blue.

nitrite under the release of $\mathrm{NO}_{2}$ (step 2) is endothermic. This is an indication that this reaction step is an equilibrium reaction, which is consistent with earlier reports that this reaction can occur in both directions. ${ }^{55,62,63}$

As noted above, the rate determining step of the standard SCR reaction is the oxidation of NO to nitrates (step 1) or the release of $\mathrm{NO}_{2}$ (step 2). The calculated activation energies for these steps are $1.08 \mathrm{eV}$ for the nitrate formation, and $0.67 \mathrm{eV}$ for the release of $\mathrm{NO}_{2}$ (Figure 3). This indicates that the oxidation of $\mathrm{NO}$ with $\mathrm{O}_{2}$ to a $\mathrm{Cu}^{2+}$ nitrate species is the rate determining step of the standard SCR reaction.

The calculated activation energy of $1.08 \mathrm{eV}$ is somewhat higher than the measured apparent activation energy of $69 \mathrm{~kJ} / \mathrm{mol}(0.72 \mathrm{eV})$; the experimental value probably includes other factors, such as the adsorption energy of the reactants as described by the Langmuir isotherm, which have not been taken into account in the DFT calculation. 


\subsubsection{Characterization of $\mathrm{Cu}-\mathrm{CHA}$ in decoupled oxidation and reduction}

According to Scheme 1, it should be possible to perform the oxidation and reduction parts of the SCR reaction separately, by exposing the catalyst alternately to a mixture containing $\mathrm{NO}$ and $\mathrm{O}_{2}$ and a mixture containing $\mathrm{NH}_{3}$ and $\mathrm{NO}$. To verify Scheme 1, we follow the state of the catalyst in situ after oxidation in $\mathrm{NO}+\mathrm{O}_{2}$, reduction in $\mathrm{NH}_{3}+\mathrm{NO}$, and again oxidation in $\mathrm{NO}+\mathrm{O}_{2}$ by XANES, EPR and FTIR. These oxidation and reduction steps constitute a complete catalytic cycle, and therefore, the second oxidation step should restore the original state of the catalyst.
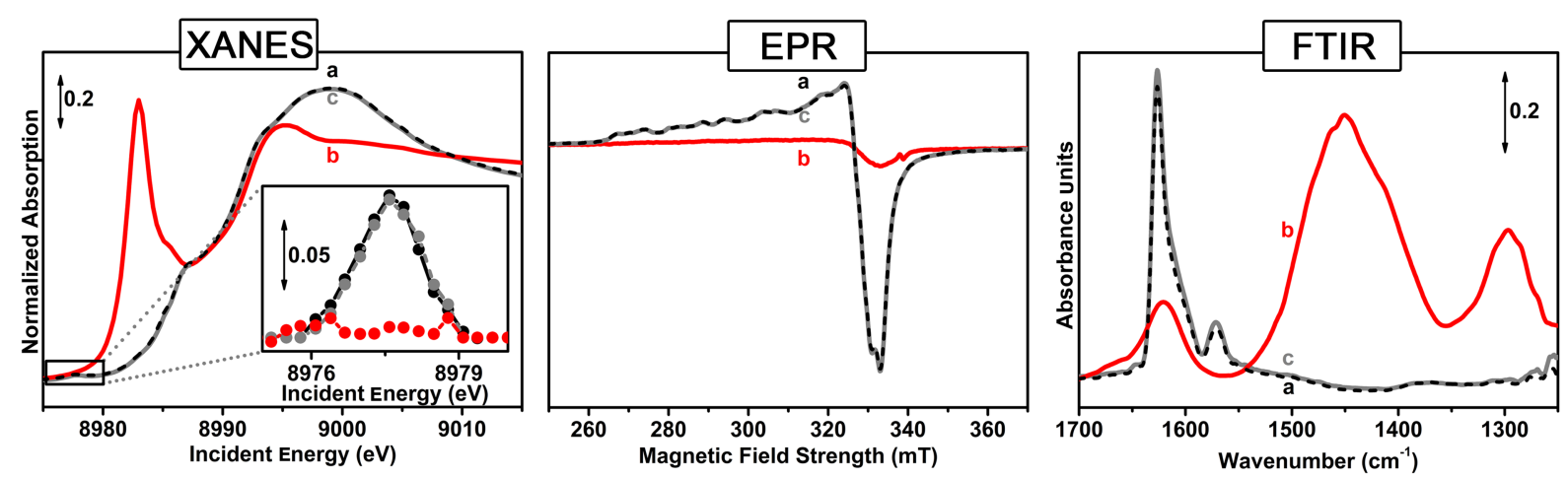

Figure 4: In situ XAS (left panel), EPR (middle panel), and FTIR (right panel) spectra collected during reduction and oxidation in SCR over of $\mathrm{Cu}-\mathrm{CHA}(2.6 \mathrm{wt} \% \mathrm{Cu})$ at $200{ }^{\circ} \mathrm{C}$ in the following consecutive steps: a) initial oxidation in $1000 \mathrm{ppm} \mathrm{NO} / 10 \% \mathrm{O}_{2}$ (dashed black curves); b) reduction in $1200 \mathrm{ppm} \mathrm{NH}_{3} / 1000 \mathrm{ppm} \mathrm{NO}$ (solid red curve); c) reoxidation in $1000 \mathrm{ppm} \mathrm{NO} / 10 \% \mathrm{O}_{2}$ (solid grey curve). Inset left panel: background-subtracted XANES pre-edge peak, characteristic for the $\mathrm{Cu}^{2+} 1 \mathrm{~s} \rightarrow 3 \mathrm{~d}$ transition, indicating the presence of $\mathrm{Cu}^{2+}$.

Figure 4 shows the $\mathrm{Cu}$ K-edge XAS spectrum in the XANES (X-ray absorption near edge structure) region, EPR, and FTIR for the Cu-CHA catalyst after initial oxidation in $\mathrm{NO}+\mathrm{O}_{2}$, after reduction in $\mathrm{NH}_{3}+\mathrm{NO}$, and after reoxidation in $\mathrm{NO}+\mathrm{O}_{2}$. All results clearly indicate that the state of the $\mathrm{Cu}$ after reoxidation is identical to that obtained after initial oxidation, indicating that the reduction and oxidation steps as performed here constitute a catalytic cycle.

The XANES and EPR spectra also provide evidence that the oxidation state changes from $\mathrm{Cu}^{2+}$ to $\mathrm{Cu}^{+}$during the exposure to $\mathrm{NH}_{3}$ and $\mathrm{NO}$ together. In particular, the XANES 


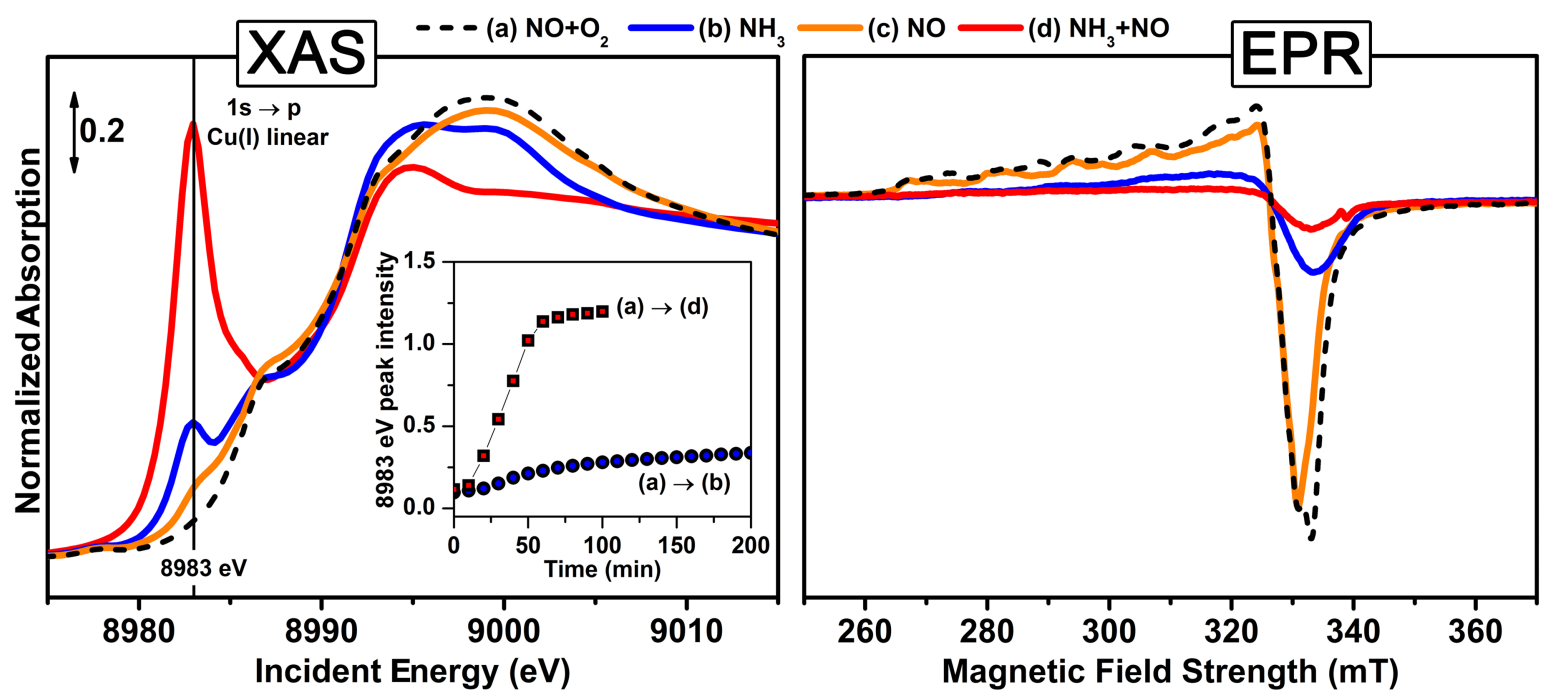

Figure 5: In situ XANES at the $\mathrm{Cu}$ K-edge (left panel) and EPR (right panel) showing the reducing capability at $200{ }^{\circ} \mathrm{C}$ of $1200 \mathrm{ppm} \mathrm{NH}_{3}$ (b: solid blue curve), $1000 \mathrm{ppm} \mathrm{NO}$ (c: solid orange curve) and a mixture of $1200 \mathrm{ppm} \mathrm{NH}_{3}$ and $1000 \mathrm{ppm} \mathrm{NO}$ (d: solid red curve) on the $\mathrm{Cu}$ (II) state obtained after initial oxidation in a mixture of $1000 \mathrm{ppm} \mathrm{NO}$ and $10 \%$ $\mathrm{O}_{2}$ (a: dashed black curve). Inset left panel: development of the intensity at $8983 \mathrm{eV}$ with time with $\mathrm{NH}_{3}$ only $(\mathrm{a} \rightarrow \mathrm{b})$ and with a mixture of $\mathrm{NH}_{3}+\mathrm{NO}(\mathrm{a} \rightarrow \mathrm{d})$, visualizing the different reduction behavior with time in these cases. In EPR, a stable state is obtained after 11 min. in $\mathrm{NH}_{3}+\mathrm{NO}$ (red), while the EPR spectra are still developing after $11 \mathrm{~min}$. in $\mathrm{NH}_{3}$ alone (blue), or $30 \mathrm{~min}$ in $\mathrm{NO}$ (orange).

spectrum measured after reduction in $\mathrm{NH}_{3}+\mathrm{NO}$ (curve b) is characterized by an intense pre-edge peak at $\sim 8983 \mathrm{eV}$, due to the $1 \mathrm{~s} \rightarrow 4 \mathrm{p}$ transitions in $\mathrm{Cu}^{+}$compounds with a low coordination number. ${ }^{44,76}$ Furthermore, the weak pre-edge peak at $\sim 8978 \mathrm{eV}$, which is a fingerprint of the $1 \mathrm{~s} \rightarrow 3 \mathrm{~d}$ transition in $\mathrm{Cu}^{2+},{ }^{54,77-81}$ has disappeared (inset in Figure 4, left panel). In EPR (Figure 4, middle panel) the signal intensity relative to the total $\mathrm{Cu}$ content decreases from 0.59 to 0.18 . (The signal intensities have been corrected according to the Boltzmann equation.) This indicates that a significant part of the $\mathrm{Cu}$ changes from an EPR active $\mathrm{Cu}^{2+}$ to the EPR silent $\mathrm{Cu}^{+}$state. This change in oxidation state is in line with Scheme 1, and reaction schemes published earlier. ${ }^{9,10,49,51}$ The EPR active species that constitutes the difference betweeen the dashed and the orange curve in Figure 4 has the spin Hamiltonian parameters $g_{\|}=2.28$ and $A_{\|}=449 \mathrm{MHz}$, which can be assigned to a $\mathrm{Cu}^{2+}$ nitrate species. ${ }^{82}$ 
The FTIR spectra in Figure 4 (right panel) after initial $\mathrm{NO}+\mathrm{O}_{2}$ exposure (curve a) reveal the appearance of IR bands at $1627(\mathrm{~s}), 1607(\mathrm{sh})$ and $1570(\mathrm{w}) \mathrm{cm}^{-1}$; all three bands are associated to $\mathrm{NO}_{3}{ }^{-}$coordinated to $\mathrm{Cu}$ sites. ${ }^{69}$ The nitrate bands promptly disappear upon interaction with the $\mathrm{NO}+\mathrm{NH}_{3}$ mixture, and the final spectrum (curve b) is dominated by bands related to strongly adsorbed $\mathrm{NH}_{3}$ species. In particular, bands at 1620 and 1297 $\mathrm{cm}^{-1}$ are associated to asymmetric and symmetric $\mathrm{N}-\mathrm{H}$ bending vibration of molecular $\mathrm{NH}_{3}$ adsorbed on $\mathrm{Cu}$ sites, respectively. The frequencies of these modes found by DFT are 1640 and $1321 \mathrm{~cm}^{-1}$, which agrees well with the experimental values. The bending $\mathrm{N}-\mathrm{H}$ vibration of $\mathrm{NH}_{3}$ adsorbed on Brønsted sites in form of $\mathrm{NH}_{4}{ }^{+}$-ions shows a maximum at $1460 \mathrm{~cm}^{-1} .^{83}$ The complete disappearance of these bands upon $\mathrm{NO}+\mathrm{O}_{2}$ exposure and final restoration of the initial state dominated by $\mathrm{Cu}$ nitrate features (curve c) prove the reoxidation and closes the SCR cycle.

Following Scheme 1, the reduction of $\mathrm{Cu}^{2+}$ to $\mathrm{Cu}^{+}$requires both $\mathrm{NH}_{3}$ and NO. As a consequence, the reduction should result in different states of the $\mathrm{Cu}$, if one of these components is missing. This is confirmed by the results reported in Figure 5, which shows XANES spectra at the $\mathrm{Cu}$ K-edge and EPR for $\mathrm{Cu}$-CHA in the presence of $\mathrm{NO}$ or $\mathrm{NH}_{3}$ alone at 200 ${ }^{\circ} \mathrm{C}$, together with that obtained in the presence of both $\mathrm{NO}$ and $\mathrm{NH}_{3}$.

The XANES spectra clearly show that exposure to NO alone at $200{ }^{\circ} \mathrm{C}$ essentially leads to a $\mathrm{Cu}^{2+}$ state that is similar to the $\mathrm{Cu}^{2+}$ obtained with oxidation in a mixture of $\mathrm{NO}$ and $\mathrm{O}_{2}$. This indicates that interaction with NO alone does not result in significant reduction of the $\mathrm{Cu}^{2+}$ species at this temperature. In EPR, exposure to NO alone leads to an EPR spectrum that is identical to that obtained with dehydrated $\mathrm{Cu}-\mathrm{CHA} .{ }^{29}$ Upon oxidation with $\mathrm{NO}$ and $\mathrm{O}_{2}$, however, a difference is observed, indicating that an additional $\mathrm{Cu}$ species is formed in this case. This suggests that a fully oxidized $\mathrm{Cu}^{2+}$ species in the 6-ring is obtained in both cases, but that oxidation in the mixture of $\mathrm{NO}$ and $\mathrm{O}_{2}$ also produces a $\mathrm{Cu}^{2+}$ species that is not located in the 6-ring.

In the presence of $\mathrm{NH}_{3}$ alone, the pre-edge peak at $\sim 8983 \mathrm{eV}$, which is characteristic for a 
$\mathrm{Cu}^{+}$species, is remarkably less pronounced, compared to that obtained with the mixture of $\mathrm{NO}$ and $\mathrm{NH}_{3}$, and it develops much slower (see inset Figure 5, left panel). This indicates that the combination of $\mathrm{NO}$ and $\mathrm{NH}_{3}$ results in a different state of the $\mathrm{Cu}$, compared to the state obtained upon exposure to $\mathrm{NO}$ or $\mathrm{NH}_{3}$ alone, in good agreement with previous results. ${ }^{49,51}$ In EPR, exposure to $\mathrm{NH}_{3}$ alone at $200{ }^{\circ} \mathrm{C}$ leads to a decrease of the signal intensity to $29 \%$, relative to the total amount of $\mathrm{Cu}$, in $11 \mathrm{~min}$, and a further decrease to $19 \%$ in about $3 \mathrm{~h}$. In a mixture of $\mathrm{NO}$ and $\mathrm{NH}_{3}$, the EPR signal decreases to $18 \%$ in $11 \mathrm{~min}$, clearly showing that the reduction is faster in this case. These results indicate that the $\mathrm{NO} / \mathrm{NH}_{3}$ mixture acts as a different, more powerful, reducing agent that is essential in the reducing part of the SCR reaction.

\subsubsection{Identification of the $\mathrm{Cu}^{+}$and $\mathrm{Cu}^{2+}$ states}

A more detailed analysis of the XAS and FTIR data in Figures 4 and 5 provides information on the identity of the $\mathrm{Cu}^{+}$and $\mathrm{Cu}^{2+}$ species. In Figure 6 we compare the in situ XAS spectra of $\mathrm{Cu}-\mathrm{CHA}$ in the presence of $\mathrm{NH}_{3}$ only and $\mathrm{NH}_{3}+\mathrm{NO}$, shown in Figure 5, with those for the linear $\left[\mathrm{Cu}^{\mathrm{I}}\left(\mathrm{NH}_{3}\right)_{2}\right]^{+}$and square planar $\left[\mathrm{Cu}^{\mathrm{II}}\left(\mathrm{NH}_{3}\right)_{4}\right]^{2+}$ amino-complexes in solution, which have been measured as a reference. The XAS spectrum of the $\mathrm{Cu}-\mathrm{CHA}$ zeolite after reduction in the $\mathrm{NH}_{3}+\mathrm{NO}$ mixture at $200{ }^{\circ} \mathrm{C}$ is almost identical to that of the linear $\left[\mathrm{Cu}^{\mathrm{I}}\left(\mathrm{NH}_{3}\right)_{2}\right]^{+}$ complex, both in the XANES and in the EXAFS regions. This provides strong evidence for a substantial reduction of the $\mathrm{Cu}$ in the catalyst to a $\mathrm{Cu}^{+}$state, and reveals that the $\mathrm{Cu}$ is predominantly present as a $\left[\mathrm{Cu}^{\mathrm{I}}\left(\mathrm{NH}_{3}\right)_{2}\right]^{+}$complex, after reduction in a mixture of NO and $\mathrm{NH}_{3}$ at $200{ }^{\circ} \mathrm{C}$. As judged from the $\mathrm{Cu}-\mathrm{N}$ coordination number of about 2 in the first shell (see panel c in Figure 6) and the lack of a second shell contribution associated with the $\mathrm{Cu}-\mathrm{Si}$ or $\mathrm{Cu}-\mathrm{Al}$ coordination, ${ }^{28,52}$ the $\mathrm{Cu}$ is only weakly bound to the zeolite. This suggests that the $\mathrm{Cu}$ is mobile, even at $200{ }^{\circ} \mathrm{C}$. It is noted that the linear $\left[\mathrm{Cu}^{\mathrm{I}}\left(\mathrm{NH}_{3}\right)_{2}\right]^{+}$ complex is not specifically mentioned in Scheme 1, but it can be regarded as $\mathrm{NH}_{3}$ adsorbed on $\mathrm{Cu}^{+}$. 

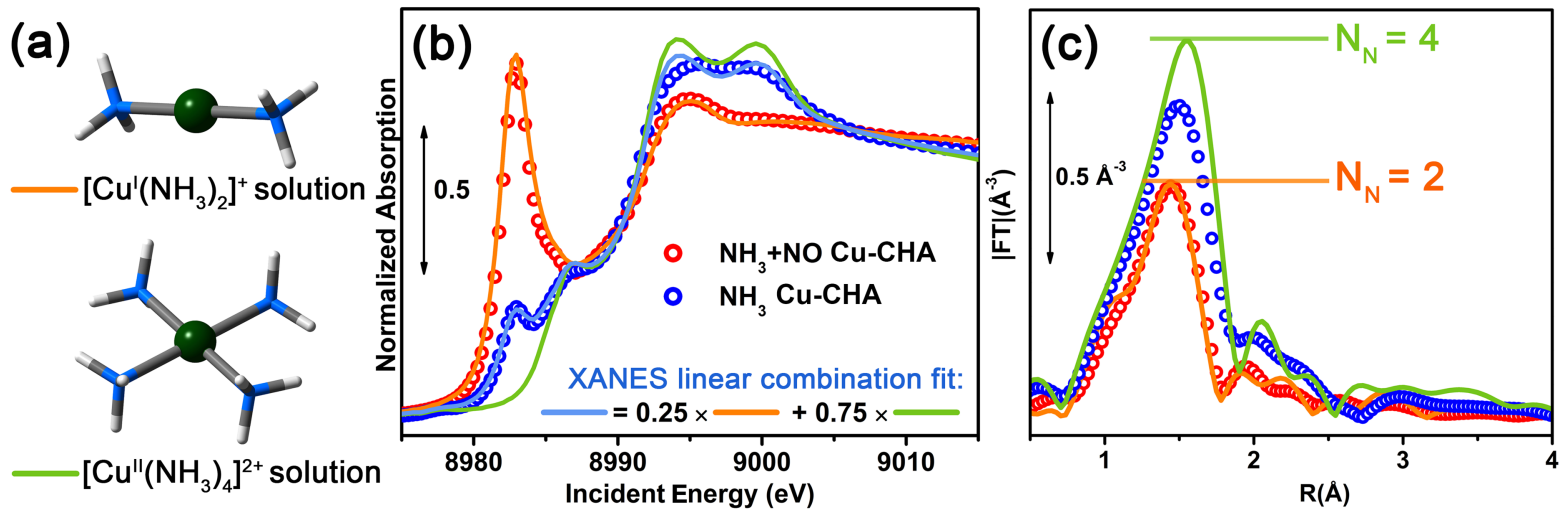

Figure 6: (a) The linear $\left[\mathrm{Cu}^{\mathrm{I}}\left(\mathrm{NH}_{3}\right)_{2}\right]^{+}$and square planar $\left[\mathrm{Cu}^{\mathrm{II}}\left(\mathrm{NH}_{3}\right)_{4}\right]^{2+}$ complexes: $\mathrm{Cu}$ : green; N: blue; H: white. (b) Cu-K XANES spectra and (c) Fourier Transformed EXAFS in the k-range 2.4-12.4 $\AA^{-1}$ of the $\mathrm{Cu}$-amino complexes (orange and green solid lines), compared to the data for $\mathrm{Cu}-\mathrm{CHA}$ exposed to $1200 \mathrm{ppm} \mathrm{NH}_{3}$ and $1200 \mathrm{ppm} \mathrm{NH}_{3} / 1000 \mathrm{ppm} \mathrm{NO}$ at $200{ }^{\circ} \mathrm{C}$ (empty circles). Panel (b) also shows that the spectrum for $\mathrm{Cu}-\mathrm{CHA}$ reduced in 1200 ppm $\mathrm{NH}_{3}$ corresponds to a linear combination of $25 \%\left[\mathrm{Cu}^{\mathrm{I}}\left(\mathrm{NH}_{3}\right)_{2}\right]^{+}$and $75 \%\left[\mathrm{Cu}^{\mathrm{II}}\left(\mathrm{NH}_{3}\right)_{4}\right]^{2+}$ (light blue solid line). The data indicate that $\mathrm{Cu}$ is mostly reduced to $\mathrm{Cu}^{+}$in a mixture of $\mathrm{NO}$ and $\mathrm{NH}_{3}$ at $200{ }^{\circ} \mathrm{C}$, while the majority of $\mathrm{Cu}$ remains in the $\mathrm{Cu}^{2+}$ state when exposed to $\mathrm{NH}_{3}$.

After reduction with $\mathrm{NH}_{3}$ alone, the intensity at $8983 \mathrm{eV}$ in the $\mathrm{Cu} \mathrm{K}$-edge remains lower than that obtained after reduction in a mixture of $\mathrm{NO}$ and $\mathrm{NH}_{3}$ (see Figure 5). In Figure 6, this spectrum is compared as well to those for the $\left[\mathrm{Cu}^{\mathrm{I}}\left(\mathrm{NH}_{3}\right)_{2}\right]^{+}$and $\left[\mathrm{Cu}^{\mathrm{II}}\left(\mathrm{NH}_{3}\right)_{4}\right]^{2+}$ amino-complexes. The measured XANES spectrum is well reproduced with a contribution of approximately $75 \%$ of the square-planar $\left[\mathrm{Cu}^{\mathrm{II}}\left(\mathrm{NH}_{3}\right)_{4}\right]^{2+}$ complex and $25 \%$ of the linear $\left[\mathrm{Cu}^{\mathrm{I}}\left(\mathrm{NH}_{3}\right)_{2}\right]^{+}$complex. This clearly indicates that a majority of the $\mathrm{Cu}$ species is present as $\mathrm{Cu}^{2+}$, and therefore is not reduced by $\mathrm{NH}_{3}$ alone at $200{ }^{\circ} \mathrm{C}$, confirming the conclusion that the mixture of $\mathrm{NH}_{3}$ and $\mathrm{NO}$ is a stronger reducing agent than $\mathrm{NH}_{3}$ alone. The first shell coordination number in this case is between 2 and 4 , as expected for a mixture of $\left[\mathrm{Cu}^{\mathrm{II}}\left(\mathrm{NH}_{3}\right)_{4}\right]^{2+}$ and $\left[\mathrm{Cu}^{\mathrm{I}}\left(\mathrm{NH}_{3}\right)_{2}\right]^{+}$complexes.

The reaction scheme also postulates that oxidation of $\mathrm{Cu}^{+}$by $\mathrm{NO}+\mathrm{O}_{2}$ or $\mathrm{NO}_{2}$ leads to identical $\mathrm{Cu}$-species. Earlier in this section we have identified these species by FTIR and EPR spectroscopy as nitrates on $\mathrm{Cu}^{2+}$ (Figure 4, right panel). Figure 7 (right panel) shows that the same set of vibrational bands is observed after oxidation of the $\mathrm{Cu}^{+}$species in a 
mixture of $\mathrm{NO}$ and $\mathrm{O}_{2}$ or $\mathrm{NO}_{2}$. The higher overall intensity of this set of bands obtained with only $\mathrm{NO}_{2}$ in the gas feed indicates that nitrate formation is more efficient in this case. Figure 7 (middle panel) shows that the Cu K-edge XANES and Fourier transformed EXAFS spectra for the $\mathrm{Cu}^{2+}$ state obtained by oxidation in $\mathrm{NO} / \mathrm{O}_{2}$ or $\mathrm{NO}_{2}$ are identical, thus confirming that oxidation of $\mathrm{Cu}^{+}$by $\mathrm{NO}+\mathrm{O}_{2}$ or $\mathrm{NO}_{2}$ leads to the same $\mathrm{Cu}^{2+}$ species.
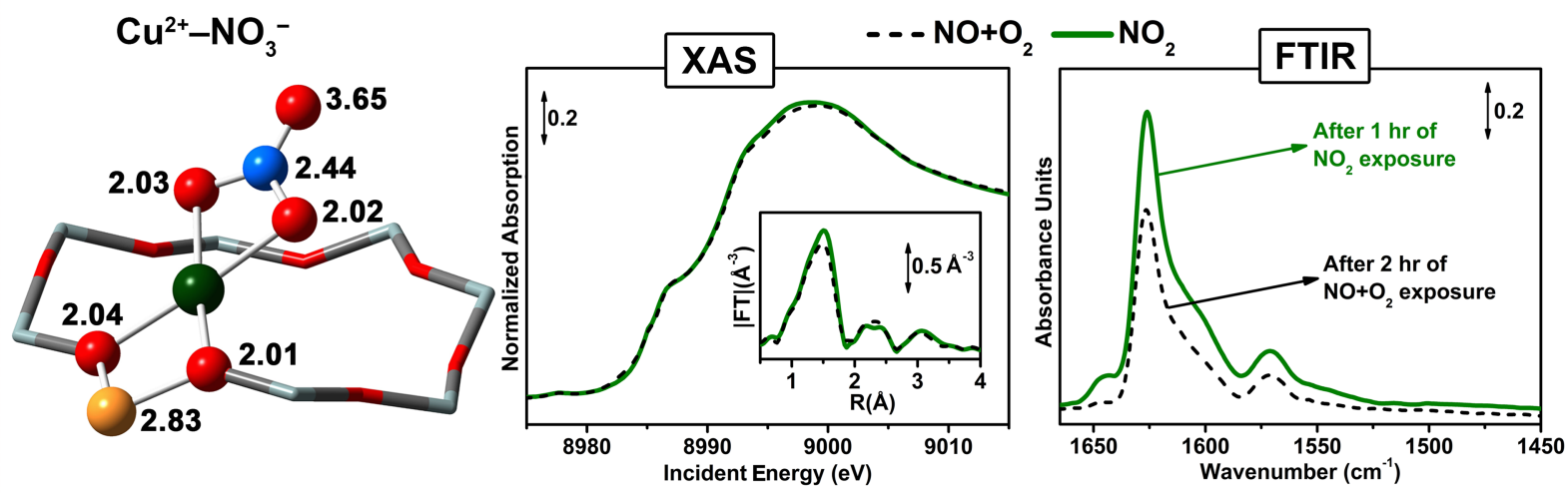

Figure 7: Structure of the bidentate $\mathrm{Cu}-\mathrm{NO}_{3}{ }^{-}$species (left panel). In situ XAS and Fourier transformed EXAFS (middle panel) and FTIR (right panel) spectra after exposure of dehydrated $\mathrm{Cu}-\mathrm{CHA}$ to $1000 \mathrm{ppm} \mathrm{NO}$ (solid green curves), and to a mixture of $1000 \mathrm{ppm} \mathrm{NO}$ and $10 \% \mathrm{O}_{2}$ (dashed black curves) at $200{ }^{\circ} \mathrm{C}$. The left panel indicates the distances from the central $\mathrm{Cu}$ atom to the neighboring atoms in $\AA$. Color code atoms: $\mathrm{Cu}$ : green, O: red, N: blue, Al: yellow.

A more detailed EXAFS analysis after oxidation of the $\mathrm{Cu}-\mathrm{CHA}$ in an $\mathrm{NO} / \mathrm{O}_{2}$ mixture reveals the structure of the nitrate species (Figure 7 , middle panel). It is important to note that the Fourier transformed EXAFS does not show a significant contribution in the 2.8-3.0 $\AA$ range, which is typical for the $\mathrm{Cu}-\mathrm{Cu}$ distance, indicating a predominantly monomeric $\mathrm{Cu}$ species. The contribution of the second shell at $\sim 2.5 \AA$ indicates a contribution of a $\mathrm{Si}$ or $\mathrm{Al}$ atom of the zeolite framework, which means that the $\mathrm{Cu}$ is bound to the zeolite framework. These features rule out a bridging nitrate configuration between neighboring $\mathrm{Cu}^{2+}$ ions, in agreement with previous studies. ${ }^{27,28} \mathrm{~A}$ number of different configurations for the nitrate species were optimized by DFT and tried in the EXAFS analysis, and by far the best agreement with the EXAFS data was obtained with a chelating bidentate nitrate on a single $\mathrm{Cu}^{2+}$ site, close to $1 \mathrm{Al}$ atom; this structure is shown in Figure 7, left panel, 
and is also indicated in Scheme 1, species B. DFT calculations also show that the bidentate configuration of the nitrate group on the $\mathrm{Cu}^{2+}$ site is the most stable. The feature around $3 \AA$ in the Fourier transformed EXAFS corresponds to a coordination geometry around the $\mathrm{Cu}$ center that is very specific for a bidentate nitrate species. The DFT calculations of the chelating bidentate nitrate ligand also reveal a vibrational mode at $1570 \mathrm{~cm}^{-1}$ associated with the stretching mode of the $\mathrm{N}=\mathrm{O}$-bond that points away from the $\mathrm{Cu}$-ion. Consequently, the vibrational bands at $1627(\mathrm{~s}), 1607(\mathrm{sh})$ and $1570(\mathrm{w}) \mathrm{cm}^{-1}$ in the FTIR spectrum, observed after oxidation in $\mathrm{NO} / \mathrm{O}_{2}$ or $\mathrm{NO}_{2}$ correspond to a chelating bidentate nitrate configuration on a monomeric $\mathrm{Cu}$-species. ${ }^{63,69,75}$

\section{The nitrate - nitrite equilibrium}

From the discussion above, we find that the $\mathrm{Cu}^{2+}$ species formed upon reaction of a $\mathrm{Cu}^{+}$with $\mathrm{NO}+\mathrm{O}_{2}$ or $\mathrm{NO}_{2}$ is a bidentate nitrate species $\left(\mathrm{Cu}^{2+}-\mathrm{NO}_{3}{ }^{-}\right.$, species $\left.\mathrm{B}\right)$. According Scheme 1, the reaction of $\mathrm{NO}_{2}$ with the $\mathrm{Cu}^{+}$should result in a nitrite species. However, as mentioned above, step 2 in Scheme 1 is an equilibrium reaction, ${ }^{63}$ and, consequently, an exposure of $\mathrm{Cu}^{+}$to $\mathrm{NO}_{2}$ results in the formation of a nitrate species, ${ }^{55,59,63,64}$ under the release of NO. To understand why generally nitrate species are found in an in situ measurement of $\mathrm{Cu}-\mathrm{CHA}$, we consider the equilibrium between nitrates and nitrites (step 2), and the formation of $\mathrm{NO}_{2}$ in the gas phase.

The equilibrium between nitrates and nitrites can be written as follows (step 2):

$$
\mathrm{NO}_{3}{ }^{-}+\mathrm{NO}(\mathrm{g}) \rightleftharpoons \mathrm{NO}_{2}^{-}+\mathrm{NO}_{2}(\mathrm{~g})
$$

The equilibrium constant $K$ associated with the equilibrium reaction in Eq. (4) is written as:

$$
K=\frac{p_{\mathrm{NO}_{2}}}{p_{\mathrm{NO}}}
$$


where $p_{\mathrm{NO}_{2}}$ and $p_{\mathrm{NO}}$ are the partial pressures of $\mathrm{NO}_{2}$ and $\mathrm{NO}$, respectively. To calculate the value of the equilibrium constant in Eq. (5), the standard Gibbs free energy $\left(\Delta G^{0}\right)$ of the equilibrium reaction is estimated using the tabulated values for the Gibbs free energy of formation ${ }^{84}\left(\Delta G_{f}^{0}\right)$ for alkali nitrates, the corresponding nitrites, $\mathrm{NO}$, and $\mathrm{NO}_{2} \cdot{ }^{85}$ At 200 ${ }^{\circ} \mathrm{C}, \Delta G^{0}$ is found to be +40 to $+50 \mathrm{~kJ} / \mathrm{mol}$, which corresponds to an equilibrium constant of $3.0 \cdot 10^{-6}$ to $3.8 \cdot 10^{-5}$. With an NO concentration of $500 \mathrm{ppm}$ in the gas, this corresponds to equilibrium concentrations of $\mathrm{NO}_{2}$ in the range 2-20 ppb. The formation of nitrite and $\mathrm{NO}_{2}$ by reaction with $\mathrm{NO}$ will only occur if the concentration of $\mathrm{NO}_{2}$ is below the equilibrium concentration, otherwise the reaction proceeds in the other direction.

The low value of the equilibrium constant implies that the steady-state concentration of $\mathrm{NO}_{2}$ in the SCR reaction must be low for the reaction to proceed. In the SCR reaction, $\mathrm{NO}_{2}$ reacts according to the fast-SCR reaction, Eq. (2), and the higher rate of that reaction compared to the standard SCR reaction can ensure such a low steady-state concentration. A steady state concentration of this magnitude and the corresponding low concentration of the nitrite species, is difficult to determine experimentally in in situ measurements.

Another consequence of the very low equilibrium concentrations of $\mathrm{NO}_{2}$ is that the equilibrium shifts to the nitrate side, already at concentrations well below $1 \mathrm{ppm}$. In most experimental setups some $\mathrm{NO}_{2}$ will always be present in mixtures of $\mathrm{NO}$ and $\mathrm{O}_{2}$ due to the oxidation of $\mathrm{NO}$ to $\mathrm{NO}_{2}$ in the gas phase. The kinetics of this reaction is well known from atmospheric chemistry. ${ }^{86}$ Using a third order rate law $r=k c_{\mathrm{NO}}^{2} c_{\mathrm{O}_{2}}$ and the rate constant $k$ (in $\mathrm{L} \mathrm{mol}^{-2} \mathrm{~s}^{-2}$ ) given by $k=1.2 \cdot 10^{3} \mathrm{e}^{530 / T},\left(T\right.$ is the temperature in $\mathrm{K}$ ), ${ }^{86}$ it is calculated that it takes only a few seconds to produce $2-20$ ppb $\mathrm{NO}_{2}$ in a mixture of $500 \mathrm{ppm}$ NO and $10 \%$ oxygen at $200{ }^{\circ} \mathrm{C}$. This means that, in practice, a mixture of $\mathrm{NO}$ and $\mathrm{O}_{2}$ contains an amount of $\mathrm{NO}_{2}$ that is higher than the estimated equilibrium concentration, and hence, the equilibrium is usually shifted towards the nitrates in the presence of $\mathrm{NO}$ and $\mathrm{O}_{2}$. It is noted that the gas phase oxidation of $\mathrm{NO}$ to $\mathrm{NO}_{2}$ is several orders of magnitude slower than the catalytic SCR reaction, which is capable of converting a few hundred ppm of NO 
in milliseconds. Therefore the contribution of the gas phase oxidation of $\mathrm{NO}$ to $\mathrm{NO}_{2}$ in the $\mathrm{SCR}$ reaction is negligible.

When there is no oxygen present in the gas phase, then the concentration of $\mathrm{NO}_{2}$ can become low enough to shift the equilibrium in Eq. (4) towards the nitrite side, and observe a transient release of $\mathrm{NO}_{2}$ upon exposure of the nitrate phase to NO. ${ }^{62,64}$ This effect is also shown in Figure 8, which shows the changes in the EPR signal of the Cu-CHA catalyst when the oxygen is removed from a $1000 \mathrm{ppm} \mathrm{NO} / 10 \% \mathrm{O}_{2}$ mixture. The difference between the orange and black spectrum in Figure 8) corresponds to a tetragonal $\mathrm{Cu}^{2+}$ species with parallel spin Hamiltonian parameter values $g_{\|}=2.28$ and $A_{\|}=449 \mathrm{MHz}$. These values are close to those for the $\mathrm{Cu}$-species found after adsorption of $\mathrm{NO}_{2}$ on $\mathrm{Cu}-\mathrm{MFI} g_{\|}=2.29$ and $A=462 \mathrm{MHz}$, and assigned to a $\mathrm{Cu}^{2+}$-nitrate species. ${ }^{82}$ This shows that the $\mathrm{Cu}^{2+}-\mathrm{NO}_{3}{ }^{-}$ species reacts with $\mathrm{NO}$. Upon removing the $\mathrm{O}_{2}$, a transient formation of $\mathrm{NO}_{2}$ is observed, and the amount of this $\mathrm{NO}_{2}$ correlates to the amount of EPR active species that disappears, when the $\mathrm{O}_{2}$ is removed (see Figure 8).

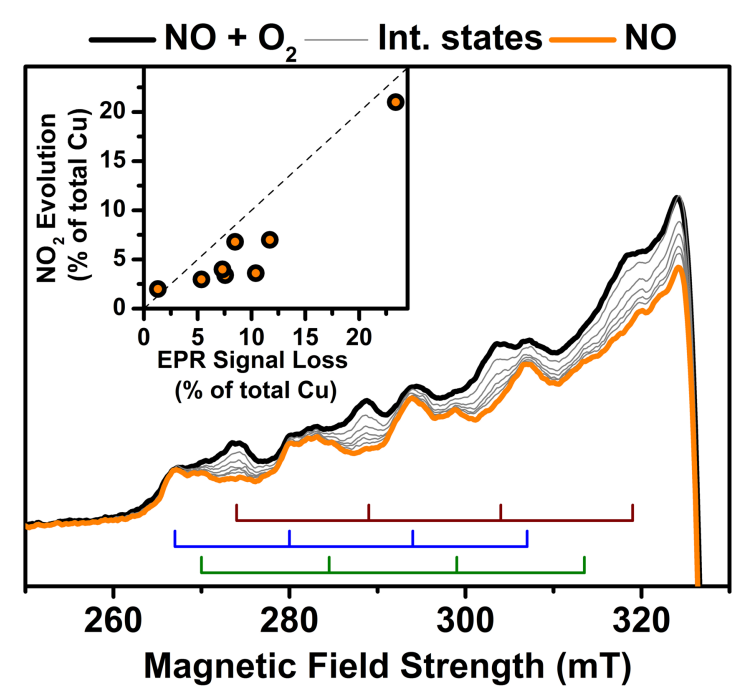

Figure 8: EPR of Cu-CHA after exposure to $\mathrm{NO} / \mathrm{O}_{2}$ at $250^{\circ} \mathrm{C}$ (black) and the transformation in the first $30 \mathrm{~min}$. after the $\mathrm{O}_{2}$ has been removed. The final spectrum is shown in orange. The sets of lines corresponding to 3 different $\mathrm{Cu}^{2+}$ species are shown: The two persistent sets (green and blue) corrrespond to two different $\mathrm{Cu}^{2+}$ sites in the 6-ring. The set that disappears (brown) corresponds to the $\mathrm{Cu}^{2+}-\mathrm{NO}_{3}{ }^{-}$species. Inset: Transient amount of $\mathrm{NO}_{2}$ formed compared with the quantified loss of EPR signal intensity for 8 independent experiments on fresh and reused $\mathrm{Cu}-\mathrm{CHA}$ samples. 
As we only observe the disappearance of the EPR signal with $g_{\|}=2.28$, and not the development of a new feature, it is concluded that the $\mathrm{Cu}$-nitrite $\mathrm{Cu}^{2+}-\mathrm{NO}_{2}^{-}$is $\mathrm{EPR}$ inactive. The remaining species (orange curve in Figure 8 is similar to that observed after dehydration of a Cu-CHA catalyst. ${ }^{29}$ These EPR signals, corresponding to $\mathrm{Cu}^{2+}$ in 6 -ring sites are persistent and are present both in an atmosphere of NO only and in a mixture of $\mathrm{NO}$ and $\mathrm{O}_{2}$ at $200{ }^{\circ} \mathrm{C}$. This indicates that the $\mathrm{Cu}^{2+} 6$-ring sites do not form nitrates under the experimental conditions used in this EPR experiment.

\section{NO oxidation as rate determining step in standard SCR}

In Scheme 1, we have identified the oxidation of NO to nitrate as the rate determining step of the standard SCR reaction. This contradicts the conclusions of Ruggeri et al., who ruled out the NO oxidation as the rate determining step for the SCR reaction, based on the very low rate of $\mathrm{NO}$ oxidation on a Cu-zeolite. ${ }^{66}$ These opposing conclusions can be reconciled by realizing that the $\mathrm{NO}$ oxidation reaction over a $\mathrm{Cu}$ zeolite is also the result of a complete catalytic cycle and not of a single reaction step. The NO oxidation part in Scheme 1 does not represent a complete catalytic cycle, since the oxidation state of the $\mathrm{Cu}$ changes from $\mathrm{Cu}^{+}$ to $\mathrm{Cu}^{2+}$, and therefore this part alone does not correctly represent the catalytic oxidation of $\mathrm{NO}$ to $\mathrm{NO}_{2}$ over a $\mathrm{Cu}$-zeolite.

If we assume that the catalytic oxidation of $\mathrm{NO}$ to $\mathrm{NO}_{2}$ take place on a $\mathrm{Cu}^{+}$site, as is the case in the SCR reaction, then the formation of $\mathrm{NO}_{2}$ is accompanied by an oxidation of the $\mathrm{Cu}^{+}$to $\mathrm{Cu}^{2+}$. However, the reduction of this $\mathrm{Cu}^{2+}$ to $\mathrm{Cu}^{+}$will be much slower than in the SCR reaction, as there is no possibility for the very efficient reduction with $\mathrm{NH}_{3}$ and NO in the catalytic oxidation of $\mathrm{NO}$ to $\mathrm{NO}_{2}$. This is supported by the XANES results, which show only a $\mathrm{Cu}^{2+}$ species in the $\mathrm{Cu}-\mathrm{CHA}$ in the presence of $\mathrm{NO}$ and $\mathrm{O}_{2}$ and no $\mathrm{Cu}^{+}$species. This means that the oxidation of $\mathrm{NO}$ in the absence of $\mathrm{NH}_{3}$ is limited by a slow reduction 
of $\mathrm{Cu}^{2+}$ to $\mathrm{Cu}^{+}$, while the SCR reaction is limited by the NO oxidation to nitrate. This is a first explanation how a Cu-zeolite can be a good catalyst for SCR, but a poor catalyst for the oxidation of $\mathrm{NO}$ to $\mathrm{NO}_{2}$, even though the $\mathrm{NO}$ oxidation is the rate determining step in the standard SCR reaction.

A second explanation is that $\mathrm{NO}$ oxidation in the absence of $\mathrm{NH}_{3}$ proceeds via an entirely different pathway than depicted in Scheme 1. In fact, the low equilibrium concentration of $\mathrm{NO}_{2}$ in transition from nitrate to nitrite species (step 2), as estimated above, would actually limit the possible yield of $\mathrm{NO}_{2}$ to a very low level. This suggests that NO oxidation in the absence of $\mathrm{NH}_{3}$ can not proceed in this way. Following this argumentation, the oxidation of $\mathrm{NO}$ to $\mathrm{NO}_{2}$ in the absence of $\mathrm{NH}_{3}$ is different from the $\mathrm{NO}$ oxidation step in the standard $\mathrm{SCR}$ reaction. The rates of $\mathrm{NO}$ oxidation in the absence and presence of $\mathrm{NH}_{3}(\mathrm{SCR})$ then become different, and therefore, no conclusion on the NO oxidation rate in SCR can be made based on measurements of $\mathrm{NO}$ oxidation in the absence of $\mathrm{NH}_{3}$. The conclusion that the oxidation of $\mathrm{NO}$ to $\mathrm{NO}_{2}$ requires a $\mathrm{Cu}$ dimer, while the $\mathrm{SCR}$ reaction can proceed on a single $\mathrm{Cu}$-ion, is a good illustration of this scenario. ${ }^{12,36}$

\section{Standard SCR, fast SCR, and slow SCR}

From Scheme 1, it follows that NO is required in both the oxidation and the reduction part of the SCR reaction. However, $\mathrm{NO}_{2}$ can also be reduced by $\mathrm{NH}_{3}$ to produce $\mathrm{N}_{2}$ and $\mathrm{H}_{2} \mathrm{O}$ in the absence of NO, according to:

$$
8 \mathrm{NH}_{3}+6 \mathrm{NO}_{2} \rightarrow 7 \mathrm{~N}_{2}+12 \mathrm{H}_{2} \mathrm{O}
$$

This reaction is slower than the fast and standard SCR reactions, and is known as 'slow SCR' reaction. Based on Scheme 1, it is straightforward to understand the chemistry that controls the rate of the standard, fast and slow SCR reactions. The rate of the standard SCR reaction is controlled by the oxidation of $\mathrm{NO}$ to $\mathrm{NO}_{2}$. In fast $\mathrm{SCR}$, this rate-determining 
step is bypassed, which explains why the fast SCR is faster than the standard SCR.

NO plays a dual role in the standard SCR reaction: it is required both for the oxidation of $\mathrm{Cu}^{+}$to $\mathrm{Cu}^{2+}$, and for the reduction of $\mathrm{Cu}^{2+}$ to $\mathrm{Cu}^{+}$, together with $\mathrm{NH}_{3}$. In fast SCR, NO is no longer required for the oxidation part, but it is still needed for the reduction of the $\mathrm{Cu}^{2+}$ species. This is the reason why the fast SCR also requires NO, and according to Scheme 1, the optimal conditions are obtained for equimolar amounts of $\mathrm{NO}$ and $\mathrm{NO}_{2}$.

In the slow SCR reaction, Eq. (6), the fast reduction of $\mathrm{Cu}^{2+}$ cannot occur as NO is not available. Consequently, the slow SCR reaction involves different reaction steps and reaction intermediates for the reduction of $\mathrm{Cu}^{2+}$ to $\mathrm{Cu}^{+}$, which apparently are slower. This implies that the chemistry of the slow SCR reaction is actually different from that of the standard and fast SCR reactions. The fact that the slow SCR reaction is slower also illustrates the importance of NO for the reduction part of the standard and fast SCR reactions.

\section{Role of $\mathrm{Cu}$-dimers and Brønsted sites}

According to Scheme 1, the SCR reaction does not require the presence of Cu-dimers or Brønsted sites. All reaction intermediates are accomodated on isolated $\mathrm{Cu}$ ions, and the calculated stability of the intermediates (Figure 3) seems sufficient for the reaction to occur in such a way. This is consistent with a constant activity per $\mathrm{Cu}$ atom. ${ }^{47}$ Nevertheless, the formation of $\mathrm{Cu}$ dimers can still be beneficial for the SCR reaction. Measurements actually show an increase in the activity per $\mathrm{Cu}$ site with increasing $\mathrm{Cu}$ loading for SCR over Cu-SSZ13 catalysts. ${ }^{39,40}$ As the propensity for $\mathrm{Cu}$-dimer formation increases with $\mathrm{Cu}$ loading, this may indicate that $\mathrm{Cu}$-dimers could enhance the rate of the $\mathrm{NH}_{3}$-SCR reaction. A possible scenario is that the oxygen leaves a single O-atom on each $\mathrm{Cu}$-ion. Then, the rate-limiting nitrate formation in Scheme 1 could be circumvented according to $2 \mathrm{Cu}^{+}+2 \mathrm{NO}+\mathrm{O}_{2} \rightarrow$ $2 \mathrm{NO}_{2}{ }^{-}-\mathrm{Cu}^{2+}$, leading to a faster SCR reaction.

The effect of Brønsted sites on the SCR reaction is limited. ${ }^{12,22}$ As adsorption sites for 
ammonia, Brønsted sites may influence the SCR reaction by an interaction with neighboring $\mathrm{Cu}$-species. The conclusions that Brønsted sites promote the SCR reaction in Fe-zeolite catalysts $^{23}$ and that the SCR activity of Cu-SAPO-34 catalysts increases proportionally with acid density seem to support such an influence. An interesting observation is that pairs of $\mathrm{NH}_{4}{ }^{+}$in H-ZSM-5 and mordenite zeolites show SCR activity with $\mathrm{NO}_{2}(\mathrm{~g})$ species. ${ }^{3}$ In Scheme 1, this would imply that Brønsted sites can contribute to the activity of the fast SCR cycle. As the fast SCR cycle is also a part of the standard SCR reaction, Brønsted sites may influence the standard SCR reaction in this way.

\section{Conclusions}

For the first time, a consistent reaction scheme for the complete catalytic cycle of the standard and fast SCR reactions is presented. The reaction scheme describes the standard SCR reaction cycle as a coupling of an NO oxidation step to the fast SCR reaction, running at equal rates. This leads to the correct stoichiometry for the standard SCR reaction, while the mass and charge balances are maintained in each step. The coupling is made by the release of an $\mathrm{NO}_{2}$ molecule in a reaction of $\mathrm{NO}$ with a nitrate species, leaving a nitrite species at the catalytic site. The $\mathrm{NO}_{2}$ molecule that is released, forms an identical nitrite species elsewhere in the catalyst.

The reaction scheme shows, that it is conceivable that the SCR reaction proceeds on a single $\mathrm{Cu}$-ion in the zeolite, without the need of $\mathrm{Cu}$-dimer formation or interaction with Brønsted acidic sites.

The reaction scheme has been corroborated experimentally in three ways, using a $\mathrm{Cu}-$ CHA catalyst. First, a reduction in a mixture of $\mathrm{NO}$ and $\mathrm{NH}_{3}$ followed by oxidation in a mixture of $\mathrm{NO}$ and $\mathrm{O}_{2}$ restores the original state of the catalyst, showing that these steps constitute a catalytic cycle. Secondly, the same bidentate nitrate species $\left(\mathrm{Cu}-\mathrm{NO}_{3}{ }^{-}\right)$is formed upon exposure of the $\mathrm{Cu}^{+}$state to a mixture of $\mathrm{NO}$ and $\mathrm{O}_{2}$ or to $\mathrm{NO}_{2}$, which confirms 
that the standard and fast SCR reactions follow the same scheme. Finally, the reduction of $\mathrm{Cu}^{2+}$ to $\mathrm{Cu}^{+}$requires the presence of both $\mathrm{NH}_{3}$ and $\mathrm{NO}$. The product of this reduction is a weakly bound $\left[\mathrm{Cu}^{\mathrm{I}}\left(\mathrm{NH}_{3}\right)_{2}\right]^{+}$linear species, which can be regarded as a $\mathrm{Cu}^{+}$covered with $\mathrm{NH}_{3}$. A reaction of the $\mathrm{Cu}^{2+}$ state with $\mathrm{NH}_{3}$ alone leads primarily to a $\left[\mathrm{Cu}^{\mathrm{II}}\left(\mathrm{NH}_{3}\right)_{4}\right]^{2+}$ complex. Exposure of the $\mathrm{Cu}^{2+}$ to $\mathrm{NO}$ alone at $200{ }^{\circ} \mathrm{C}$ does not lead to a measurable reduction of the $\mathrm{Cu}$.

All reaction steps are exothermic, except the formation of a $\mathrm{Cu}^{2+}$-nitrite by reaction of $\mathrm{NO}$ with $\mathrm{Cu}^{2+}$-nitrate. The latter reaction is an equilibrium reaction that depends on the partial pressures of $\mathrm{NO}$ and $\mathrm{NO}_{2}$. Under typical conditions for SCR, the equilibrium partial pressure of $\mathrm{NO}_{2}$ is on the order of 2-20 ppb, indicating that the steady-state partial pressure of $\mathrm{NO}_{2}$ in $\mathrm{SCR}$ is very low. As gas phase oxidation of $\mathrm{NO}$ and $\mathrm{O}_{2}$ can produce such amounts of $\mathrm{NO}_{2}$ in a few seconds, nitrate species are typically observed in a mixtures of $\mathrm{NO}$ and $\mathrm{O}_{2}$ as well.

All reaction steps involved in the fast SCR reaction are also part of the standard SCR reaction. As a consequence, the rate determining step must involve the oxidation of NO by $\mathrm{O}_{2}$; a density functional theory calculation of the activation energies in a $\mathrm{Cu}-\mathrm{CHA}$ point to the formation of a bidentate nitrate $\left(\mathrm{Cu}-\mathrm{NO}_{3}{ }^{-}\right)$species as the rate determining step.

To resolve the apparent contradiction that the oxidation of $\mathrm{NO}$ by $\mathrm{O}_{2}$ is rate determining in the standard $\mathrm{SCR}$ reaction over a Cu-zeolite, while such catalysts have a much lower activity for the oxidation of $\mathrm{NO}$ to $\mathrm{NO}_{2}$, it is realized that the rates of the $\mathrm{SCR}$ and $\mathrm{NO}$ oxidation reactions are the result of two different catalytic cycles. In the absence of $\mathrm{NH}_{3}$, the reduction of $\mathrm{Cu}^{2+}$ to $\mathrm{Cu}^{+}$cannot occur in the same way as in the SCR reaction, and the reduction of $\mathrm{Cu}^{2+}$ to $\mathrm{Cu}^{+}$becomes rate determining in the oxidation of $\mathrm{NO}$ to $\mathrm{NO}_{2}$. Alternatively, the oxidation of $\mathrm{NO}$ to $\mathrm{NO}_{2}$ follows a reaction path that does not involve a $\mathrm{Cu}^{+}$species. 


\section{$9 \quad$ Experimental}

The Cu-CHA sample was prepared using a similar method as reported earlier. ${ }^{27}$ A synthesis gel with the composition $1.0 \mathrm{SiO}_{2}: 0.0667 \mathrm{Al}: 0.5 \mathrm{TMAdaOH}: 0.5 \mathrm{HF}: 3 \mathrm{H}_{2} \mathrm{O}$ was prepared by dissolving aluminum isopropoxide (98\%, Sigma-Aldrich) in tetraethyl orthosilicate (98\% Aldrich) and adding N,N,N-trimethyladamantammonium hydroxide (TMAdaOH, 25 wt.\%, Sachem) to the solution. This mixture was stirred to homogenize overnight. Hydrofluoric acid (48 wt.\%, 99.99\% trace-metal basis, Sigma-Aldrich) was added and the mixture was stirred by hand. Water was evaporated from the gel at $60{ }^{\circ} \mathrm{C}$ under regular homogenization by hand until the desired content was obtained. To form the CHA zeolite, the gel was heated to $150{ }^{\circ} \mathrm{C}$ for 3 days under rotation in a teflon-lined autoclave. The CHA product was recovered by filtration and washed several times with water, followed by calcination at $580{ }^{\circ} \mathrm{C}$ for 3 hours to remove the TMAdaOH. Copper ions were introduced by suspending the calcined CHA in $250 \mathrm{~mL}$ (per gram zeolite) $5 \mathrm{mM}$ copper(II)acetate solution and stirred at room temperature for $24 \mathrm{~h}$. Finally, the product was filtered, washed and calcined in air at $500{ }^{\circ} \mathrm{C}$ for $3 \mathrm{~h}$. The final $\mathrm{Cu}-\mathrm{CHA}$ obtained and used in this work had a $\mathrm{Si} / \mathrm{Al}=15$ and a $\mathrm{Cu} / \mathrm{Al}=0.48$, corresponding to a $\mathrm{Cu}$ content of $2.6 \mathrm{wt} \%$.

The measurement of the NO conversion was done in a microreactor, using a $5 \mathrm{mg}$ sample of the $\mathrm{Cu}$-CHA catalyst (sieve fraction 150-300 $\mu \mathrm{m}$ ) in a quartz U-tube reactor with $2 \mathrm{~mm}$ inner diameter. The composition of the reactor exit gas was determined using a Gasmet CX400 FTIR spectrometer connected to the outlet of the reactor. The catalyst was heated for 1 hour at $550{ }^{\circ} \mathrm{C}$, in an atmosphere of $500 \mathrm{ppm} \mathrm{NO}, 533 \mathrm{ppm} \mathrm{NH}_{3}, 5 \% \mathrm{H}_{2} \mathrm{O}$, and 10 $\% \mathrm{O}_{2}$ in $\mathrm{N}_{2}$ at a flow rate of $225 \mathrm{Nml} / \mathrm{min}$. The catalyst was then stepwise cooled down to $160{ }^{\circ} \mathrm{C}$, using the same flow and gas composition. In each step, the sample was kept at a constant temperature for $20 \mathrm{~min}$. The conversion of $\mathrm{NO}$ was determined based on the averaged concentration measured during the final 5 min. in each step.

Spin polarized Density Functional Theory (DFT) calculations were used to estimate the free energies of the reaction intermediates at $200{ }^{\circ} \mathrm{C}$. The calculations were performed with 
the GPAW package, ${ }^{87,88}$ using a real space grid-based projector augmented wave method. A grid spacing of $h=0.2$ and a Fermi smearing of $0.1 \mathrm{~K}$ were found sufficient to obtain a satisfactory convergence of the relative energies. The BEEF-vdW functional ${ }^{89}$ was used to account for the Van der Waals interactions. ${ }^{90}$ This functional has shown to produce reliable results for the interaction of molecules with zeolites. ${ }^{91,92}$ The free energy of the adsorbed species at $200{ }^{\circ} \mathrm{C}$ was calculated based on the calculated DFT energies at $0 \mathrm{~K}$ and the vibrational frequencies, using the thermochemistry package in ASE. ${ }^{93}$ The free energies of the gas phase species at $200{ }^{\circ} \mathrm{C}$ were obtained from the Shomate equations. The zeolite was represented by periodic cells with hexagonal symmetry (cell parameters $\left.a, b=13.886 \AA, c=15.116 \AA, \alpha=120^{\circ}, \beta, \gamma=90^{\circ}\right)$, containing $36 \mathrm{~T}$ atoms.

The in situ X-ray absorption spectroscopy (XAS) measurements at the $\mathrm{Cu}$ K-edge were performed at the BM23 beamline of the European Synchrotron Radiation Facility (ESRF, Grenoble, France). A self-supported pellet $(\sim 100 \mathrm{mg})$ of the $\mathrm{Cu}-\mathrm{CHA}$ catalyst was placed in a Microtomo reactor cell connected to a gas manifold that allowed to control total gas flow and gas composition of the mixtures. Initially, the $\mathrm{Cu}-\mathrm{CHA}$ sample was heated to $400{ }^{\circ} \mathrm{C}$ at $5{ }^{\circ} \mathrm{C} / \mathrm{min}$ in $50 \% \mathrm{O}_{2} / \mathrm{He}$ at a flow of $100 \mathrm{ml} / \mathrm{min}$, and kept at those conditions until the near-edge features $(\mathrm{XANES})$ became stable $(\sim 1 \mathrm{~h})$. Then, the temperature was reduced to $200{ }^{\circ} \mathrm{C}$ and the catalyst was exposed to the different reaction gas mixtures.

The XAS measurements at the $\mathrm{Cu}$ K-edge were carried out in transmission mode, using double-crystal Si(111) monochromator and ionization chambers for the detection of the incident and transmitted photons. A copper foil was measured simultaneously as a reference for the photon energy. ${ }^{81}$ For steady state conditions, the XAS spectra were collected in a step-scan mode, at a resolution of $0.3 \mathrm{eV}$ around the edge, and a step size $\Delta k=0.035 \AA^{-1}$ in the EXAFS part, using a dwell time of 1 to $4 \mathrm{~s}$ per point. Typically, the data analysis was based on the average of 2 consecutive scans. To monitor changes in time upon changing gas atmosphere, a faster scan mode was used, with a step resolution of $0.3 \mathrm{eV}$ around the edge and a $\Delta k=0.08 \AA^{-1}$ up to $8 \AA^{-1}$ with a dwell time of $1 \mathrm{~s}$ per point; this allowed for 
collecting about 10 scans per hour.

$\left[\mathrm{Cu}^{\mathrm{I}}\left(\mathrm{NH}_{3}\right)_{2}\right]^{+}$and $\left[\mathrm{Cu}^{\mathrm{II}}\left(\mathrm{NH}_{3}\right)_{4}\right]^{2+}$ complexes were used as references for the XAS measurements. Both complexes were prepared as aqueous solutions. The $\left[\mathrm{Cu}^{\mathrm{II}}\left(\mathrm{NH}_{3}\right)_{4}\right]^{2+}$ solution ( $\sim 50 \mathrm{mM}$, deep-violet-blue color) was prepared by dissolving tetraamminecopper(II) sulfate monohydrate (Sigma Aldrich, 98\%) in water); a small amount of $\mathrm{NH}_{3}$ was added to avoid precipitation of $\mathrm{Cu}(\mathrm{OH})_{2}$. The solution was poured into a glass capillary $(\varnothing=3.5$ $\mathrm{mm})$, which was used for the XAS measurement. The $\left[\mathrm{Cu}^{\mathrm{I}}\left(\mathrm{NH}_{3}\right)_{2}\right]^{+}$complex was prepared by dropwise adding a solution of hydrazine (Sigma Aldrich, 35\%) into the capillary with the $\left[\mathrm{Cu}^{\mathrm{II}}\left(\mathrm{NH}_{3}\right)_{4}\right]^{2+}$ complex. ${ }^{94}$ In order to prevent the re-oxidation of $\mathrm{Cu}^{+}$ions by $\mathrm{O}_{2}$, the capillary was then sealed with paraffin. The $\left[\mathrm{Cu}^{\mathrm{I}}\left(\mathrm{NH}_{3}\right)_{2}\right]^{+}$solution was prepared immediately before the XAS measurements.

For the FTIR measurements, about $15 \mathrm{mg}$ of the $\mathrm{Cu}-\mathrm{CHA}$ catalyst was pressed in a self-supported pellet and placed inside a commercial FTIR reactor cell (AABSPEC, \#2000A multimode), which allows to record infrared spectra under controlled temperature and gas atmosphere. Prior to the measurements, the catalyst was heated at $400{ }^{\circ} \mathrm{C}$ for $30 \mathrm{~min}$ (heating rate $5{ }^{\circ} \mathrm{C} / \mathrm{min}$ ) in a $50 \% \mathrm{O}_{2} / \mathrm{He}$ gas mixture at a flow of $50 \mathrm{ml} / \mathrm{min}$. Then the sample was cooled down to $200{ }^{\circ} \mathrm{C}$, and exposed to the different reaction gas mixtures at a flow of $50 \mathrm{ml} / \mathrm{min}$. The FTIR spectra were recorded in transmission mode with a resolution of $2 \mathrm{~cm}^{-1}$ on a Perkin Elmer System 2000 infrared spectrophotometer equipped with a MCT detector at liquid nitrogen temperature.

The in situ EPR measurements were performed on a continuous wave X-band Bruker EMX EPR spectrometer with the ER 4102ST cavity with a gunn diode microwave source in the field interval 220-400 mT. A quartz tube (4 mm inner diameter) with a 10-20 mg sample of the Cu-CHA catalyst (150-300 $\mu \mathrm{m}$ sieve fraction); quartz wool was used to keep the sample in place. The sample was heated using preheated atmospheric air with a Bruker EMX VT unit. The quartz tube was connected to a gas manifold, allowing for changing of the gas atmosphere in the tube within seconds. The reactant gas flow was kept at 200 
NmL/min, using a Bronkhorst mass flow controller. A Thermo Electron Corporation Model 17C Ammonia Analyser was used to measure the $\mathrm{NO}_{2}$ concentration in the exit gas. The EPR spectra were measured continuously during the experiment with fast sweeps (approximately $10 \mathrm{~s}$ ) between 220 and $400 \mathrm{mT}$, with a microwave power $6.3 \mathrm{~mW}$, a modulation frequency of $100 \mathrm{kHz}$, a modulation amplitude of $8 \mathrm{G}$, at a frequency of $9.39 .7 \mathrm{GHz}$, and 1024 data points. The time between two spectra was approximately $15 \mathrm{~s}$.

\section{Acknowledgement}

CL and KAL thank the support from the Mega-grant of the Russian Federation Government to support scientific research at Southern Federal University, No.14.Y26.31.0001. SM acknowledges financial support by the Danish Independent Research Council DFF 133500175 and DFF 09-070250, and Carlsbergfondet for supporting the upgrade of the EPR instrument at the Department of Chemistry, DTU. Sachem is acknowledged for making TMAdaOH available.

\section{References}

(1) Moliner, M.; Franch, C.; Palomares, E.; Grill, M.; Corma, A. Chem. Commun. 2012, $48,8264-8266$.

(2) Rahkamaa-Tolonen, K.; Maunula, T.; Lomma, M.; Huuhtanen, M.; Keiski, R. L. Catal. Today 2005, 100, 217-222.

(3) Eng, J.; Bartholomew, C. H. J. Catal. 1997, 171, 27-44.

(4) Kato, A.; Matsuda, S.; Kamo, T.; Nakajima, F.; Kuroda, H.; Narita, T. J. Phys. Chem. 1981, 119, 4099-4102.

(5) Topsøe, N.-Y. Science 1994, 265, 1217-1219. 
(6) Grünert, W. In Urea-SCR Technology for DeNOx After Treatment of Diesel Exhausts; Nova, I., Tronconi, E., Eds.; Springer Science + Business Media: New York, 2014; pp $181-219$.

(7) Wark, M.; Brückner, A.; Liese, T.; Grünert, W. J. Catal. 1998, 61, 48-61.

(8) Went, G. T.; Leu, L.-J.; Rosin, R. R.; Bell, A. T. J. Catal. 1992, 134, 492-505.

(9) Iwasaki, M. In "Urea-SCR Technoloy for DeNOx After Treatment of Diesel Exhausts"; Nova, I., Tronconi, E., Eds.; Springer: New York, 2014; pp 221-246.

(10) Doronkin, D. E.; Casapu, M.; Günter, T.; Müller, O.; Frahm, R.; Grunwaldt, J.-D. J. Phys. Chem. C 2014, 118, 10204-10212.

(11) Zecchina, A.; Rivallan, M.; Berlier, G.; Lamberti, C.; Ricchiardi, G. Phys. Chem. Chem. Phys. 2007, 9, 3483-3499.

(12) Bates, S. A.; Verma, A. A.; Paolucci, C.; Parekh, A. A.; Anggara, T.; Yezerets, A.; Schneider, W. F.; Miller, J. T.; Delgass, W. N.; Ribeiro, F. H. J. Catal. 2014, 312, $87-97$.

(13) Vennestrøm, P. N. R.; Janssens, T. V. W.; Kustov, A.; Grill, M.; Puig-Molina, A.; Lundegaard, L. F.; Tiruvalam, R. R.; Concepción, P.; Corma, A. J. Catal. 2014, 309, 477-490.

(14) Deka, U.; Juhin, A.; Eilertsen, E. A.; Emerich, H.; Green, M. A.; Korhonen, S. T.; Weckhuysen, B. M.; Beale, A. M. J. Phys. Chem. C 2012, 116, 4809-4818.

(15) Brandenberger, S.; Kröcher, O.; Tissler, A.; Althoff, R. Catal. Rev. 2008, 50, 492-531.

(16) Qi, G.; Wang, L.; Yang, R. T. In Urea-SCR Technology for DeNOx After Treatment of Diesel Exhausts; Nova, I., Tronconi, E., Eds.; Springer Science + Business Media: New York, 2014; pp 149-177. 
(17) Ruggeri, M. P.; Grossale, A.; Nova, I.; Tronconi, E.; Jirglova, H.; Sobalik, Z. Catal. Today 2012, 184, 107-114.

(18) Berlier, G.; Zecchina, A.; Spoto, G.; Ricchiardi, G.; Bordiga, S.; Lamberti, C. J. Catal. 2003, 215, 264-270.

(19) Čapek, L.; Dědeček, J.; Sazama, P.; Wichterlová, B. J. Catal. 2010, 272, 44-54.

(20) Sobalik, Z.; Sazama, P.; Dedecek, J.; Wichterlová, B. Appl. Catal. A Gen. 2014, 474, $178-185$.

(21) Sazama, P.; Wichterlová, B.; Tábor, E.; Šťastný, P.; Sathu, N. K.; Sobalík, Z.; Dědeček, J.; Sklenák, Š.; Klein, P.; Vondrová, A. J. Catal. 2014, 312, 123-138.

(22) Bates, S. A.; Delgass, W. N.; Ribeiro, F. H.; Miller, J. T.; Gounder, R. J. Catal. 2014, 312, 26-36.

(23) Schwidder, M.; Santhosh Kumar, M.; Bentrup, U.; Pérez-Ramírez, J.; Brückner, A.; Grünert, W. Microporous Mesoporous Mater. 2008, 111, 124-133.

(24) Brandenberger, S.; Kröcher, O.; Wokaun, A.; Tissler, A.; Althoff, R. J. Catal. 2009, 268, 297-306.

(25) Llabres i Xamena, F.; Fisicaro, P.; Berlier, G.; Zecchina, A.; Turnes Palomino, G.; Prestipino, C.; Bordiga, S.; Giamello, E.; Lamberti, C. J. Phys. Chem. B 2003, 10\%, $7036-7044$.

(26) Turnes Palomino, G.; Fisicaro, P.; Bordiga, S.; Zecchina, A.; Giuria, V.; Giamello, E.; Lamberti, C. J. Phys. Chem. B 2000, 104, 4064-4073.

(27) Giordanino, F.; Vennestrøm, P. N. R.; Lundegaard, L. F.; Stappen, F. N.; Mossin, S.; Beato, P.; Bordiga, S.; Lamberti, C. Dalton Trans. 2013, 42, 12741-12761. 
(28) Borfecchia, E.; Lomachenko, K. A.; Giordanino, F.; Falsig, H.; Beato, P.; Soldatov, A. V.; Bordiga, S.; Lamberti, C. Chem. Sci. 2015, 6, 548-563.

(29) Godiksen, A.; Stappen, F. N.; Vennestrøm, P. N. R.; Giordanino, F.; Rasmussen, S. B.; Lundegaard, L. F.; Mossin, S. J. Phys. Chem. C 2014, 118, 23126-23138.

(30) Ganemi, B.; Björnbom, E.; Paul, J. Appl. Catal. B Environ. 1998, 17, 293-311.

(31) Woertink, J. S.; Smeets, P. J.; Groothaert, M. H.; Vance, M. A.; Sels, B. F.; Schoonheydt, R. A.; Solomon, E. I. Proc. Natl. Acad. Sci. U. S. A. 2009, 106, 1890818913.

(32) Smeets, P. J.; Hadt, R. G.; Woertink, J. S.; Vanelderen, P.; Schoonheydt, R. A.; Sels, B. F.; Solomon, E. I. J. Am. Chem. Soc. 2010, 132, 14736-14738.

(33) Wang, L.; Gaudet, J. R.; Li, W.; Weng, D. J. Catal. 2013, 306, 68-77.

(34) Deka, U.; Lezcano-Gonzalez, I.; Weckhuysen, B. M.; Beale, A. M. ACS Catal. 2013, 3, $414-427$.

(35) Wang, L.; Gaudet, J. R.; Li, W.; Weng, D. J. Catal. 2013, 306, 68-77.

(36) Verma, A. A.; Bates, S. A.; Anggara, T.; Paolucci, C.; Parekh, A. A.; Kamasamudram, K.; Yezerets, A.; Miller, J. T.; Delgass, W. N.; Schneider, W. F.; Ribeiro, F. H. J. Catal. 2014, 312, 179-190.

(37) Wang, D.; Zhang, L.; Li, J.; Kamasamudram, K.; Epling, W. S. Catal. Today 2014, 231, 64-74.

(38) Tsai, M.-L.; Hadt, R. G.; Vanelderen, P.; Sels, B. F.; Schoonheydt, R. A.; Solomon, E. I. J. Am. Chem. Soc. 2014, 136, 3522-3529.

(39) Gao, F.; Walter, E. D.; Kollar, M.; Wang, Y.; Szanyi, J.; Peden, C. H. J. Catal. 2014, $319,1-14$. 
(40) Gao, F.; Kwak, J. H.; Szanyi, J.; Peden, C. H. F. Top. Catal. 2013, 56, 1441-1459.

(41) Andersen, C. W.; Bremholm, M.; Vennestrøm, P. N. R.; Blichfeld, A. B.; Lundegaard, L. F.; Iversen, B. B. IUCrJ 2014, 1, 382-386.

(42) Uzunova, E. L.; Mikosch, H.; St. Nikolov, G. Int. J. Quantum Chem. 2013, 113, 723728.

(43) Szanyi, J.; Kwak, J. H.; Zhu, H.; Peden, C. H. F. Phys. Chem. Chem. Phys. 2013, 15, $2368-2380$.

(44) Giordanino, F.; Borfecchia, E.; Lomachenko, K. A.; Lazzarini, A.; Agostini, G.; Gallo, E.; Soldatov, A. V.; Beato, P.; Bordiga, S.; Lamberti, C. J. Phys. Chem. Lett. 2014, 5, 1552-1559.

(45) Göltl, F.; Hafner, J. J. Chem. Phys. 2012, 136, 064501.

(46) Deka, U.; Lezcano-Gonzalez, I.; Warrender, S. J.; Picone, A. L.; Wright, P. A.; Weckhuysen, B. M.; Beale, A. M. Microporous Mesoporous Mater. 2013, 166, 144-152.

(47) Xue, J.; Wang, X.; Qi, G.; Wang, J.; Shen, M.; Li, W. J. Catal. 2013, 297, 56-64.

(48) Göltl, F.; Bulo, R. E.; Hafner, J.; Sautet, P. J. Phys. Chem. Lett. 2013, 4, 2244-2249.

(49) Kieger, S.; Delahay, G.; Coq, B.; Neveu, B. J. Catal. 1999, 183, 267-280.

(50) Yu, T.; Hao, T.; Fan, D.; Wang, J.; Shen, M.; Li, W. J. Phys. Chem. C 2014, 118, $6565-6575$.

(51) Paolucci, C.; Verma, A. A.; Bates, S. A.; Kispersky, V. F.; Miller, J. T.; Gounder, R.; Delgass, W. N.; Ribeiro, F. H.; Schneider, W. F. Angew. Chem. Int. Ed. 2014, 53, $11828-11833$.

(52) McEwen, J. S.; Anggara, T.; Schneider, W. F.; Kispersky, V. F.; Miller, J. T.; Delgass, W. N.; Ribeiro, F. H. Catal. Today 2012, 184, 129-144. 
(53) Kispersky, V. F.; Kropf, A. J.; Ribeiro, F. H.; Miller, J. T. Phys. Chem. Chem. Phys. 2012, 14, 2229-2238.

(54) Prestipino, C.; Berlier, G.; Llabres i Xamena, F.; Spoto, G.; Bordiga, S.; Zecchina, Adriano,; Turnes Palomino, G.; Yamamoto, T.; Lamberti, C. Chem. Phys. Lett. 2002, 363, 389-396.

(55) Colombo, M.; Nova, I.; Tronconi, E. Catal. Today 2010, 151, 223-230.

(56) Long, R.; Yang, R. J. Catal 2002, 207, 274-285.

(57) Wallin, M. J. Catal. 2003, 218, 354-364.

(58) Devadas, M.; Kröcher, O.; Elsener, M.; Wokaun, A.; Mitrikas, G.; Söger, N.; Pfeifer, M.; Demel, Y.; Mussmann, L. Catal. Today 2007, 119, 137-144.

(59) Metkar, P. S.; Balakotaiah, V.; Harold, M. P. Catal. Today 2012, 184, 115-128.

(60) Ciardelli, C.; Nova, I.; Tronconi, E.; Bandl-Konrad, B. Chem. Commun. 2004, 27182719.

(61) Grossale, A.; Nova, I.; Tronconi, E.; Chatterjee, D.; Weibel, M. J. Catal. 2008, 256, $312-322$.

(62) Colombo, M.; Nova, I.; Tronconi, E. Catal. Today 2012, 197, 243-255.

(63) Wang, D.; Zhang, L.; Kamasamudram, K.; Epling, W. ACS Catal. 2013, 3, 871-881.

(64) Tronconi, E.; Nova, I. In Urea-SCR Technology for deNOx After Treatment of Diesel Exhausts; Nova, I., Tronconi, E., Eds.; Springer Science + Business Media: New York, $2014 ;$ pp 247-270.

(65) Mihai, O.; Widyastuti, C. R.; Ando, S.; Kamasamudram, K.; Li, J.; Joshi, S. Y.; Currier, N. W.; Yezerets, A.; Olsson, L. J. Catal. 2014, 311, 170-181. 
(66) Ruggeri, M. P.; Nova, I.; Tronconi, E. Top. Catal. 2013, 56, 109-113.

(67) Delahay, G.; Valade, D.; Guzmán-Vargas, A.; Coq, B. Appl. Catal. B Environ. 2005, $55,149-155$.

(68) Lamberti, C.; Groppo, E.; Spoto, G.; Bordiga, S.; Zecchina, A. Adv. Catal. 2007, 51, $1-74$.

(69) Poignant, F.; Freysz, J. L.; Daturi, M.; Saussey, J. Catal. Today 2001, 70, 197-211.

(70) Sedlmair, C.; Gil, B.; Seshan, K.; Jentys, A.; Lercher, J. A. Phys. Chem. Chem. Phys. 2003, 5, 1897-1905.

(71) Colombo, M.; Nova, I.; Tronconi, E. Appl. Catal. B Environ. 2012, 111-112, 433-444.

(72) Gao, F.; Walter, E. D.; Karp, E. M.; Luo, J.; Tonkyn, R. G.; Kwak, J. H.; Szanyi, J.; Peden, C. H. F. J. Catal. 2013, 300, 20-29.

(73) Korhonen, S. T.; Fickel, D. W.; Lobo, R. F.; Weckhuysen, B. M.; Beale, A. M. Chem. Commun. 2011, 47, 800-802.

(74) Zhang, R.; McEwen, J.-S.; Kollár, M.; Gao, F.; Wang, Y.; Szanyi, J.; Peden, C. H. F. ACS Catal. 2014, 4, 4093-4105.

(75) Hadjiivanov, K. I. Catal. Rev. 2000, 42, 71-144.

(76) Lamble, G.; Moen, A.; Nicholson, D. G. J. Chem. Soc. Faraday Trans. 1994, 90, 22112213.

(77) Kau, L. S.; Spira-Solomon, D. J.; Penner-Hahn, J. E.; Hodgson, K. O.; Solomon, E. I. J. Am. Chem. Soc. 1987, 109, 6433-6442.

(78) Sano, M.; Komorita, S.; Yamatera, H. Inorg. Chem. 1992, 31, 459-463. 
(79) Lamberti, C.; Spoto, G.; Scarano, D.; Pazé, C.; Salvalaggio, M.; Bordiga, S.; Zecchina, A.; Turnes Palomino, G.; D'Acapito, F. Chem. Phys. Lett. 1997, 269, 500508 .

(80) Groothaert, M. H.; van Bokhoven, J. A.; Battiston, A. A.; Weckhuysen, B. M.; Schoonheydt, R. A. J. Am. Chem. Soc. 2003, 125, 7629-7640.

(81) Bordiga, S.; Groppo, E.; Agostini, G.; van Bokhoven, J. A.; Lamberti, C. Chem. Rev. 2013, 113, 1736-850.

(82) Kucherov, A. V.; Gerlock, J. L.; Jen, H.-W.; Shelef, M. Zeolites 1995, 15, 15-20.

(83) Lezcano-Gonzalez, I.; Deka, U.; van der Bij, H. E.; Paalanen, P.; Arstad, B.; Weckhuysen, B. M.; Beale, A. M. Appl. Catal. B Environ. 2014, 154, 339-349.

(84) DFT calculations of gaseous $\mathrm{NO}$ and $\mathrm{NO}_{2}$ are known to be inaccurate, and hence the estimate of $\Delta G^{0}$ is based on the known values for $\Delta G_{f}^{0}$ for alkali nitrates and nitrites. ${ }^{85}$

(85) Lide, D. R., Ed. CRC Handbook of Chemistry and Physics, 78th ed.; CRC Press: Boca Raton, New York.

(86) Tsukahara, H.; Ishida, T.; Mayumi, M. Nitric Oxide 1999, 3, 191-198.

(87) Mortensen, J. J.; Hansen, L. B.; Jacobsen, K. W. Phys. Rev. B 2005, 71, 035109.

(88) Enkovaara, J.; Rostgaard, C.; Mortensen, J. J.; Chen, J.; Dułak, M.; Ferrighi, L.; Gavnholt, J.; Glinsvad, C; Haikola, V.; Hansen, H. A.; Kristoffersen, H. H.; Kuisma, M.; Larsen, A. H.; Lehtovaara, L.; Ljungberg, M.; Lopez-Acevedo, O.; Moses, P. G.; Ojanen, J.; Olsen, T.; Petzold, V.; Romero, N. A.; Stausholm-Møller, J.; Strange, M.; Tritsaris, G. A.; Vanin, M.; Walter, M.; Hammer, B.; Häkkinen, H.; Madsen, G. K. H.; Nieminen, R. M.; Nørskov, J. K.; Puska, M.; Rantala, T. T.; Schiøtz, J.; Thygesen, K. S.; Jacobsen, K. W. J. Phys. Condens. Matter, 2010, 22, 253202. 
(89) Wellendorff, J.; Lundgaard, K. T.; Møgelhøj, A.; Petzold, V.; Landis, D. D.; Nørskov, J. K.; Bligaard, T.; Jacobsen, K. W. Phys. Rev. B 2012, 85, 235149.

(90) As Van der Waals interactions are expected to contribute to the binding of molecules in zeolite pores, the BEEF-vdW functional was chosen. From a comparison with similar calculations using the standard RPBE functional, we find that introduction of the Van der Waals interactions results in a change in binding energy of $0.3 \mathrm{eV}$ at most for the fragments studied here.

(91) Brogaard, R. Y.; Moses, P. G.; Nørskov, J. K. Catal. Letters 2012, 142, 1057-1060.

(92) Brogaard, R. Y.; Weckhuysen, B. M.; Nørskov, J. K. J. Catal. 2013, 300, 235-241.

(93) ASE thermochemistry package. https://wiki.fysik.dtu.dk/ase/ase/ thermochemistry/thermochemistry.html.

(94) Moen, A.; Nicholson, D. G.; Rønning, M. J. Chem. Soc. Faraday Trans. 1995, 91, 3189-3194. 


\section{Graphical TOC Entry}

1

2

3

4

5

6

7

10

11

12

13

14

15

16

17

18

19

20

21

22

23

24

25

26

27

28

29

30

31

32

33

34

35

36

37

38

39

40

41

42

43

44

45

46

47

48

49

50

51

52

53

54

55

56

57

58

59

60

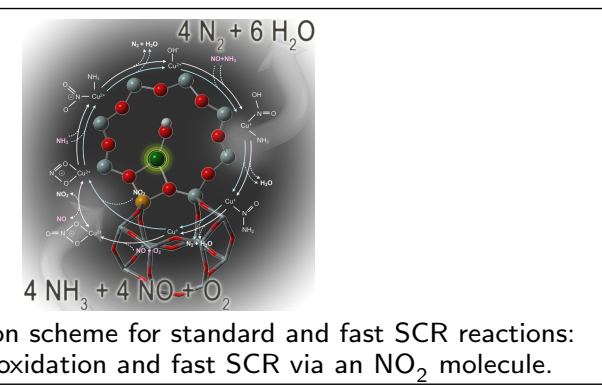

coupling the $\mathrm{NO}$ oxidation and fast $\mathrm{SCR}$ via an $\mathrm{NO}_{2}$ molecule. 